\title{
Effect of Socratic dialogic teaching on sixth grade students' attention and academic achievement
}

\author{
Ali Nouri' ${ }^{\text {": }}$ (D), Fataneh Esmaeili ${ }^{2}$, Saman Seifpour ${ }^{3}$, Anahita Khorami ${ }^{4}$ Samira Anvar ${ }^{2}$, \\ Mahmoud Talkhabi ${ }^{5}$, Fatemeh Bolbolli ${ }^{6}$, Nahid Noorian ${ }^{7}$ \\ 1. Associate Professor, Department of Educational Sciences, Malayer University, Malayer, Iran \\ 2. MA in Mind, Brain, and Education Studies, Iran \\ 3. MA in Medical Engineering, Tehrn, Iran \\ 4. $\mathrm{PhD}$ in Cognitive Neuroscience, School of Behavioral Sciences \& Mental Health, Iran Institute of Psychiatry, Iran University of Meadical \\ Sciences, Tehran, Iran \\ 5. Assistant Professor, Department of Educational Management, Farhangian University and Institute for Cognitive Science Studies, Tehran, Iran \\ 6. BA in Primary Education, Tehran, Iran \\ 7. MA in Clinical Psychology, Tehran, Iran
}

Recieved: 25 Sep. 2017

Revised: 8 May 2018

Accepted: 17 Jul. 2018

Keywords

Attention

Attention training

Socratic dialogue

Dialogic teaching

Corresponding author

Ali Nouri, Department of Educational Sciences, Malayer University, Malayer, Iran

Email: A.nouri@malayeru.ac.ir

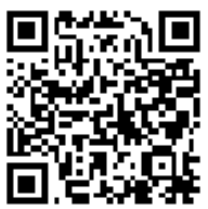

doi.org/10.30699/icss.21.2.94

\section{Abstract}

Introduction: The Socratic Dialogue is one of the effective strategies of teaching, with strong research evidence supporting its positive effects on improving student learning and thinking skills. In this regard, the present study was conducted to investigate the effect of Socratic Dialogue teaching on sixth grade students' attention and academic achievement.

Methods: This study was conducted with a mixed method approach (quasi-experimental and phenomenological). Participants in this study were 24 sixth grade male students, half of whom were in the experimental group (dialogic method) and the other half in the control group (non-dialogic method). The Attention Network Test and CPT were used for measuring the changes in the efficacy of students' attention and a multi-choice test was designed to assess students' academic performance. Event-related potentials (ERPs) were also used for recording and representing the changes in neural network of attention when they performed the attention network test. Moreover, the semi-structured interview was utilized to describe the experiences of the teachers and students in the experimental group at the end of the intervention period.

Results: Results of the study indicated that in different aspect of attention, there was a significant difference only in overall omission component of sustained attention test between the experimental and control groups. Further, there was a statistically significant difference between the mean scores of the student of the experimental and control groups on the academic achievement tests (except for mathematics) in favor of the experimental group. The ERPs data also indicated the effect of amplitude of the incongruent task at the Fz electrode and the latency of neutral task at the $\mathrm{CZ}$ electrode for the P200 component enhanced significantly after training for experimental group. Howevr, there was not a significant relationship among all measured changes for the N200 component. The analysis of the qualitative data obtained from the interview confirmed the role of the Socratic dialogue method in improving attention and academic performance.

Conclusion: These results support the positive effects of Socratic dialogue in enhancing some aspects of students' attention and their academic achievement. These effects are highly likely related to the questioning nature of dialogic learning context that encourages students to continuously control and monitor their own attention processes. 
(D)

\title{
مطالعه تاثير تدريس تَفت و شنود سقراطى بر عملكرد توجه و ييشرفت تحصيلى داشى آموزان يايه ششم ابتدايى
}

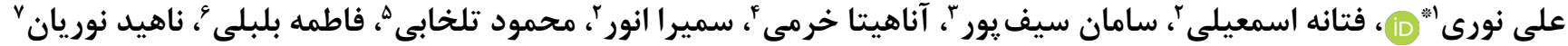

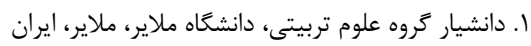

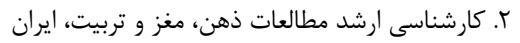

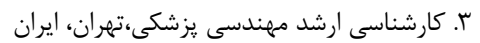

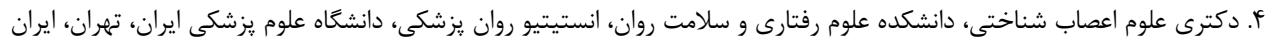

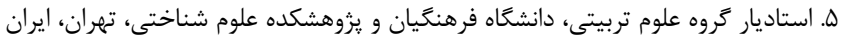

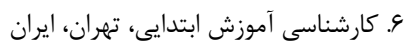

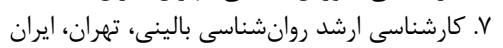

\section{DS}

مقلهمه: روش كَفت و شنود سقراطى يكى از روشهاى موثر آموزش است كه شواهد يزوهشى مستحكمى در حمايت از

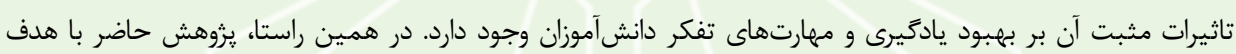
مطالعه تاثير تدريس كَفت و شنود سقراطى بر عملكرد توجه و يِيشرفت تحصيلى دانش آموزان پايه ششم ابتدايى اجرا شد. روش كار: اين يزوهش با اتخاذ يك رويكرد آميخته (تركيبى از روش آزمايشى و روش گديدارشناسى ) اجرا شد.

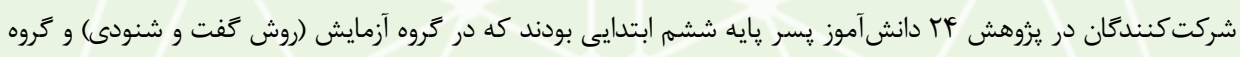
كنترل (روش غير كفت و شنودى) مشاركت داشتند. براى سنجش عملكرد توجه از آزمون شبكههاى توجه و آزمون توجه ״ايدار و براى سنجش پِيشرفت تحصيلى از آزمون عملكرد تحصيلى استفاده شد. در حين اجراى آزمون شبكههاى توجه، ֶتانسيل هاى وابسته به رخداد نيز ثبت كرديد. مصاحبه نيمه ساختاريافته نيز براى توصيف تجربه معلمان و دانش آموزان كروه آزمايش در پايان دوره آموزش اجرا شد.
\end{abstract} يافته ها: نتايج تحليل دادها نشان داد كه در ابعاد مختلف توجه، تنها در مولفه حذف كلى آزمون توجه پايدار تفاوت معنادارى در عملكرد توجه دانشآموزان بين كروه آزمايش و كنترل وجود دارد. همجنين، در همه مواد عملكرد تحصيلى به جزء رياضيات تفاوت معنادار مشاهده شد. نتايج ERPs نشان داد كه تاثير دامنه تكليف ناهمخوان در الكترود FZ و تاخير تكليف خنثى در الكترود CZ در مولفه P200 در نمرات يس آزمون كروه آزمايش به طور معنادارى افزايش يافته است. اما، ميان عناصر اندازه گيرى شده مولفه N200 تفاوت معنادارى مشاهده نشد. دادهاى كيفى حاصل از مصاحبه نيز نقش روش كَفت و شنود سقراطى در بهبود توجه و عملكرد تحصيلى دانشآموزان را تاييد نمود. نتيجه كَيرى: نتايج اين بثوهش از تاثيرات مثبت تدريس با روش كفت و شنود سقراطى در بهبود برخى جنبههاى توجه و عملكرد تحصيلى حمايت مى كند. اين تاثيرات به احتمال زياد ناشى از ماهيت برسش گرانه فضاى يادَيرى گفت و شنود است كه دانشآموزان را ترغيب مى كند تا يِيوسته فرايندهاى توجه خود را مديريت و نظارت نمايند.

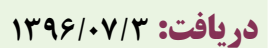

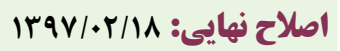

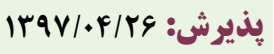
وازههاى كليدى توجه آموزش توجه

كفت و شنود سقراطى تدريس مبتنى بر كفت و شنود

نويسنله مسئول على نورى، عضو هيات علمى گروه علوم تربيتى دانشخاه ملاير، ملاير، ايران ايميل:A.nouri@malayeru.ac.ir

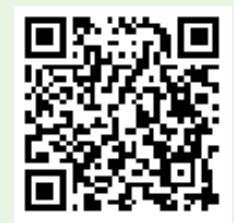

dol doi.org/10.30699/icss.21.2.94

مقدمه

نوآورانه براى برانخيختن و حفظ توجه دانش آموزان تلاش نمودهاند. در همين راستا، يروهشگران در طول دهdهاى اخير به درك گستردهاى از مبانى عصبى توجه نائل گشتهاند و شواهد زيادى در حمايت از نقش درى اساسى توجه در رشد شناختى، اجتماعى و عاطفى دانشآموزان عرضه نمودهاند (Y-Y). بر اساس نتايج اين مطالعات، سه مدار عصبى متمايز
توجه به عنوان يك سازه يِيجيده جِند وجهى مشتمل بر عناصر جند

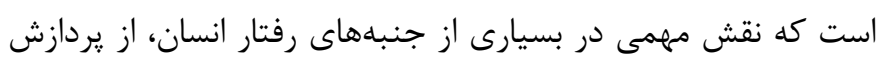
ادراكى ״ايه تا فرايندهاى شناختى و هيجانى پيیجيده ايفا مى كند (1). تربيتشناسان ييوسته بر اهميت حياتى توجه در فرايند يادگيرى و حافظه تاكيد نمودهاند. آنها همواره در جستجوى اكتشاف راهبردهاى 
شواهد رو به افزايشى در ارتباط بين توجه و كنترل كوششمند Effortful control نيز گزارش شده است (1)-11). كنترل كوششمند

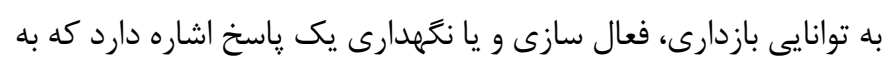

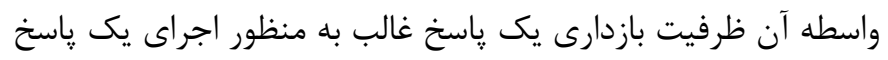

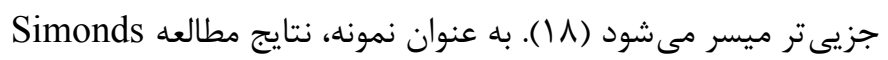

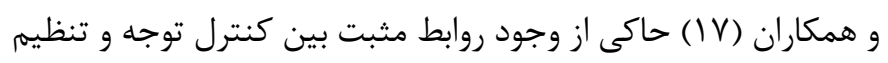
هيجان است. رشد شبكه هاى توجه مرتبط با توانايى هاى خودتنظيمى ونى

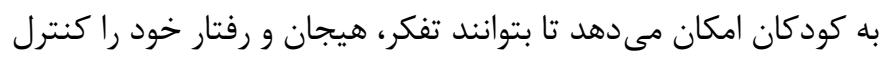
كنند (9 (1، 91، • ()). همسو با اين يافته ها، در مطالعه ديخرى با استفاده از زمان واكنش (Reaction time (RT) و پֶتانسيل هاى وابسته به رخداد (Event-related potential (ERP))، ارتباط ميان نشانههاى جامعهستيزى و سه شبكه توجه عمده (كوش به زنتىى، جهت دهى و راطيان

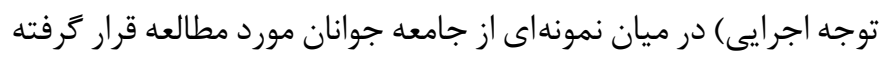

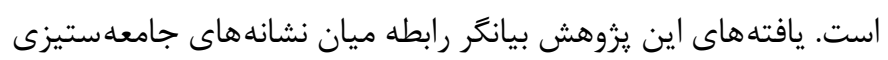

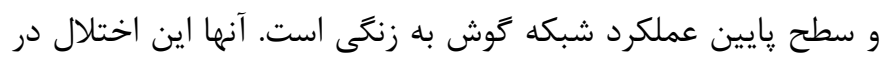

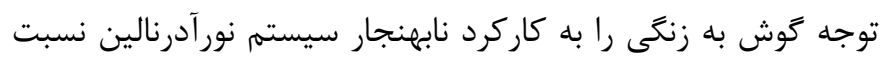
مى دهند كه ممكن است بر يردازش شناختى عالى و عاطفى تاثير

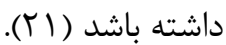

با اتكاى به نتايج مطالعات متعدد در حمايت از نقش حياتى تجربه در

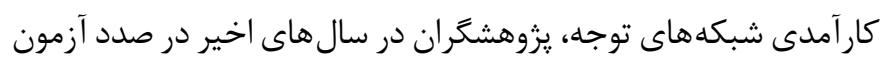

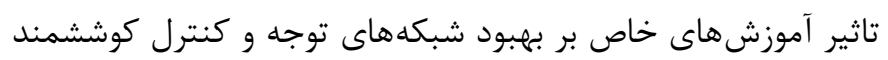

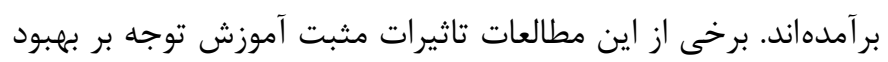

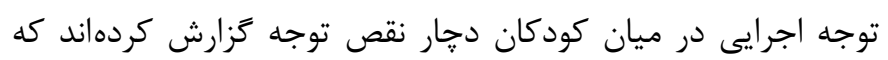

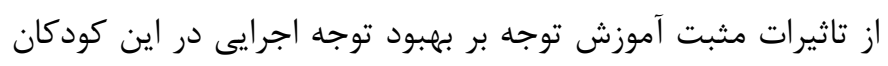

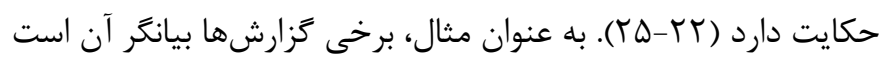

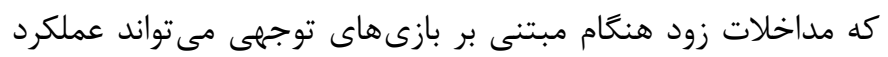

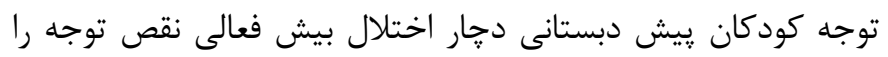

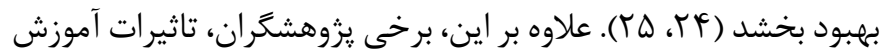

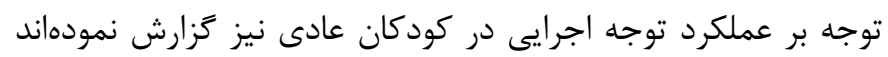

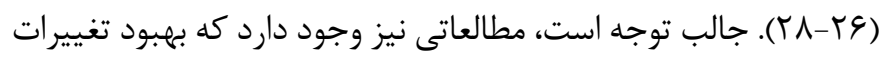
ساختارى و كاركردى در نواحى مغزى دركير توجه اجرايى از جمله

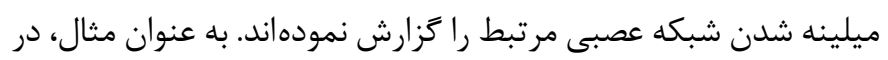

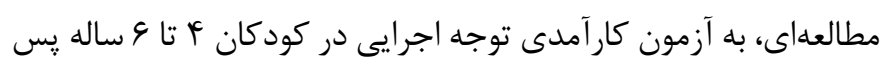
از ه روز آموزش توجه از طريق بازىهاى رايانهاى يرداخته شده است.

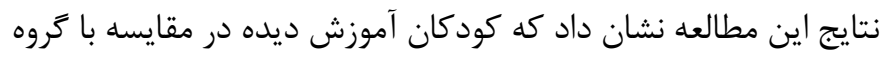

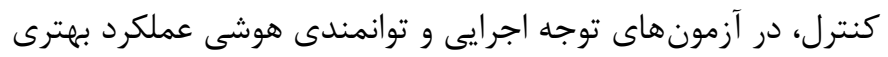

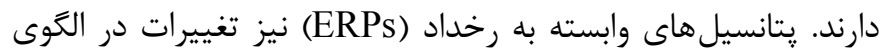

در كاركردهاى اساسى مرتبط به توجه در گير هستند (r-أا، ه). در اين مدل، كوش به زنتى به فرايند دستيابى و حفظ حالت حساسيت بالا

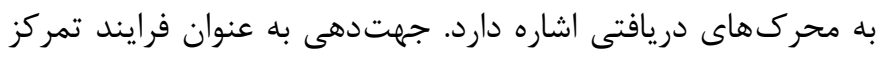
انتخابى بر اطلاعات از ورودىهاى حسى تعريف مى شود. شبكه كنترل

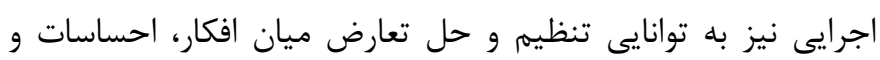

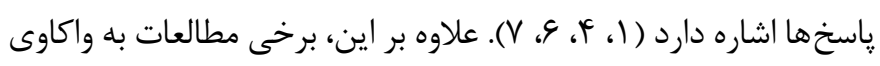

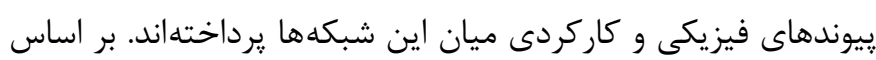

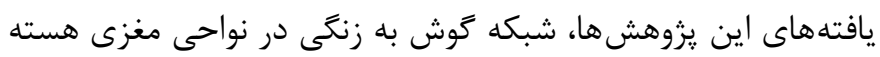

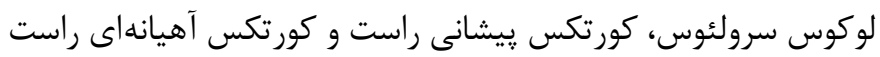
يردازش و توسط انتقال دهنده عصبى نورايىنفرين تنظيم مىشود.

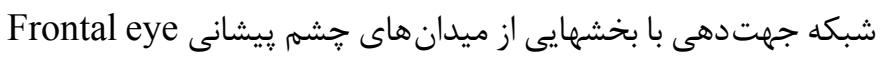

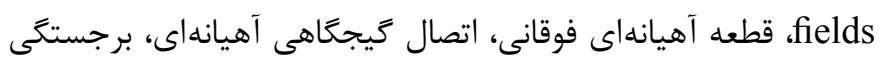
فوقانى Superior colliculus و هسته بالشتك

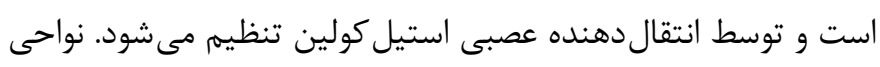

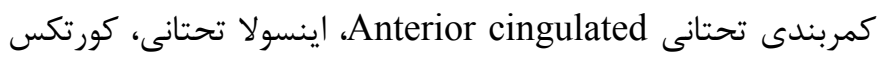
بيشانى و جسم مخطط Striatum دركير شبكه كنترل اجرايى هستند و انتقال دهنده هاى عصبى دويامين وسروتونين تنظيم كننده آن هستند ("ا، أ، 9-A). مطالعات تصويربردارى اخير نشان دادهاند كه اين سه

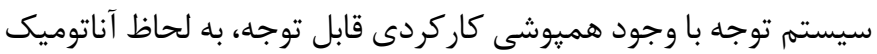

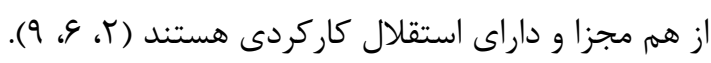

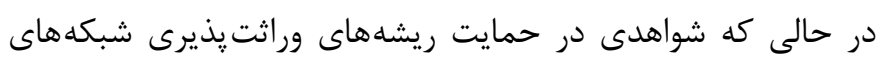

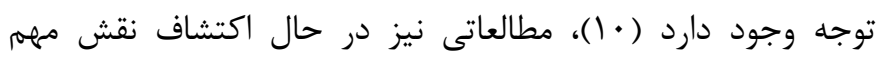

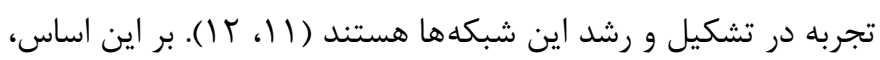

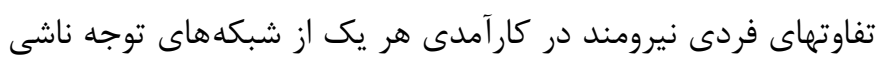

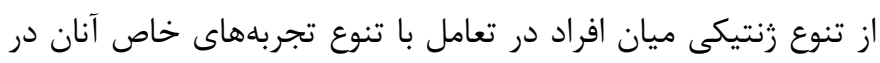

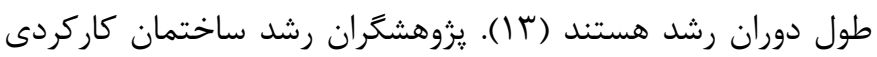

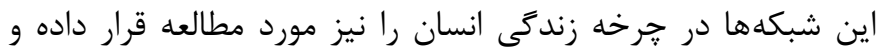

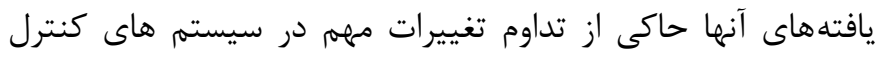

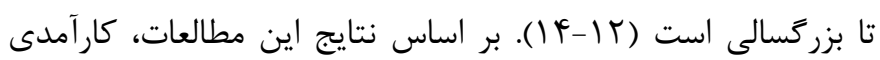

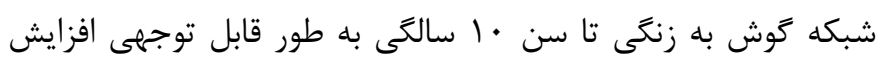

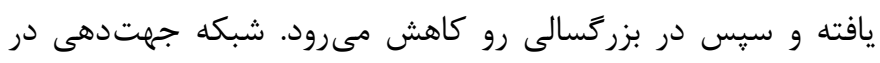

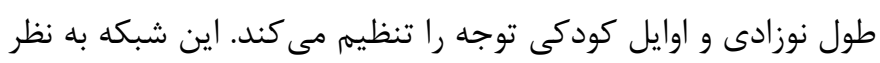

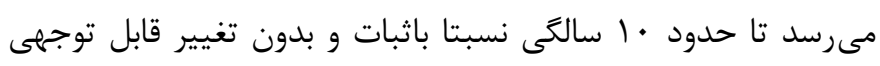

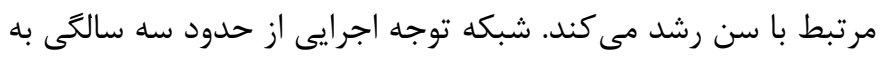

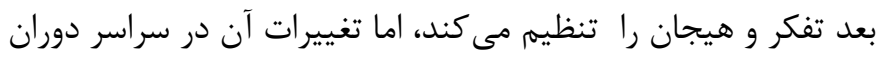

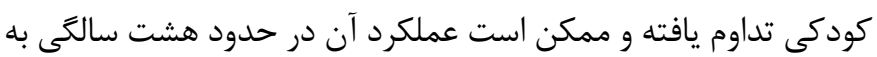

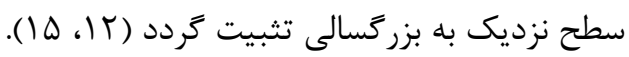


بيست و جهار قرن بيش كار آمدى خود را در عرض زمانها و مكانهاى

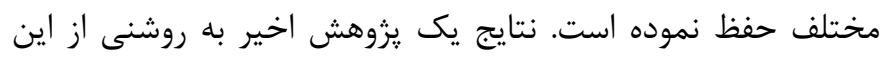

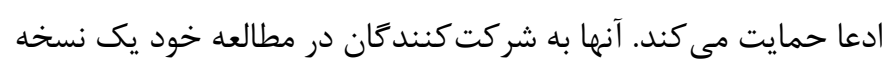

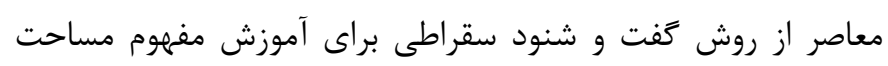

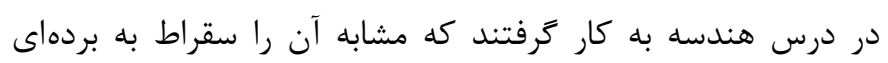

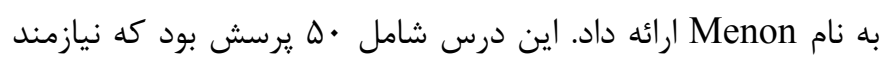

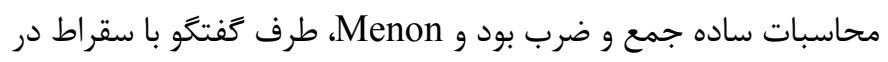

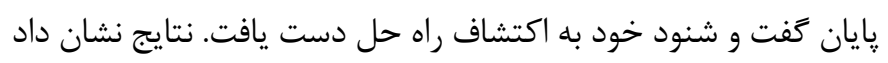

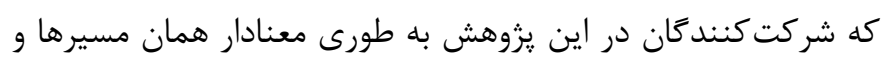

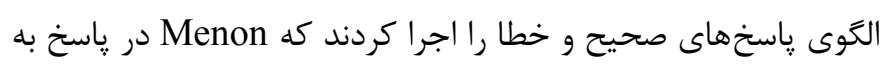
يرسش هاى سقراط اجرا كرد (سب).

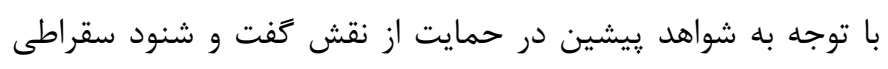

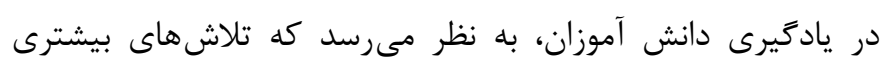

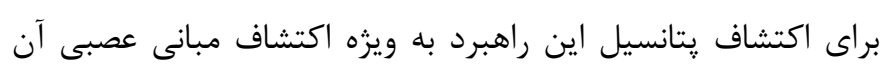

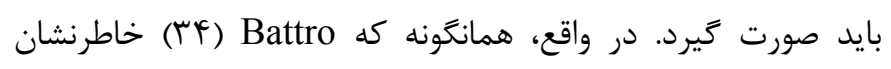

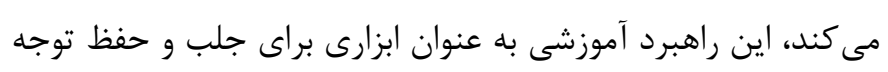

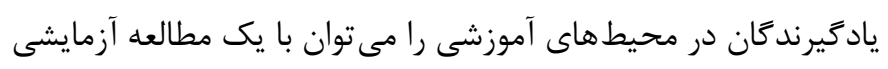

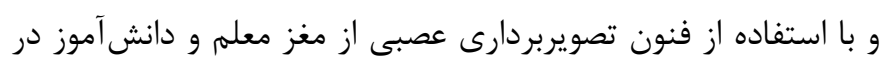

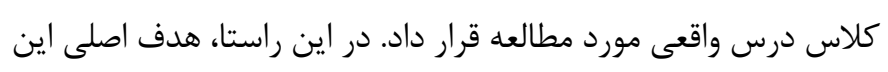

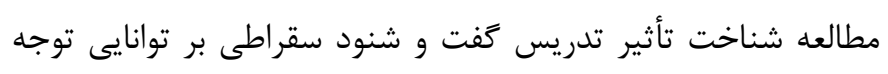

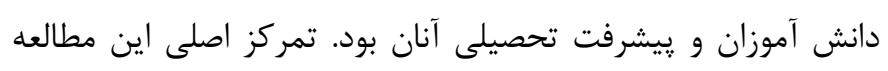

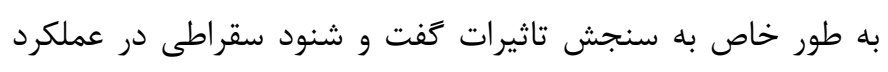

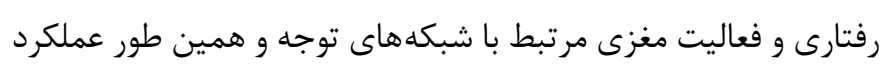

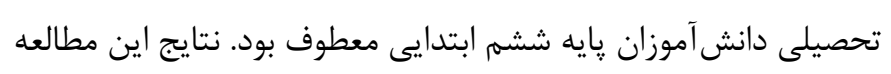

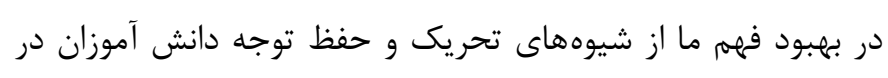

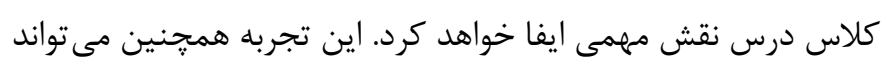

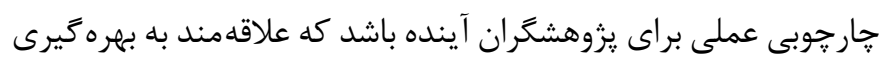

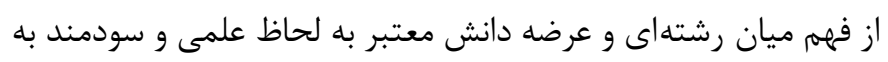

لحاظ تربيتى هستند.

\section{روش كار}

اين يزوهش با اتخاذ يك رويكرد آميخته (تركيبى از روش كمى و ورش روش

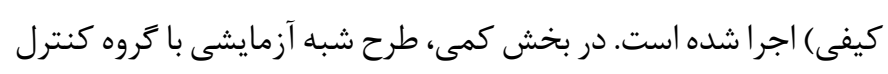

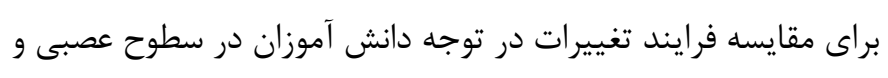

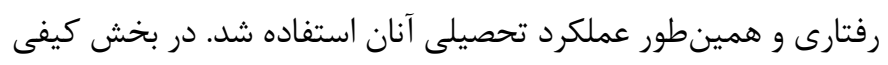

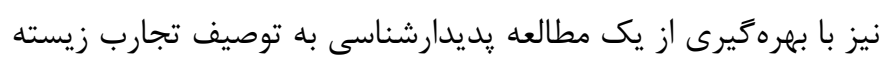

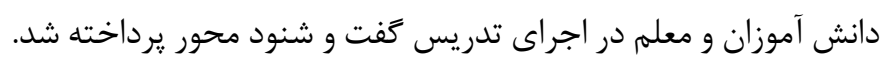

فعاليت مغز را نشان داد. به اين ترتيب كه الكوى فعاليت مغز كودكان

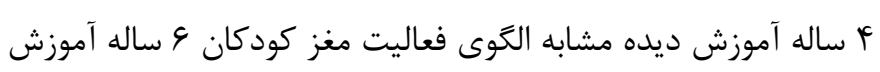

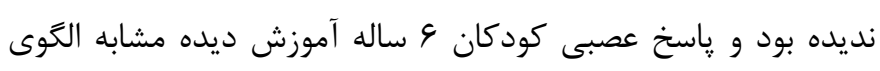

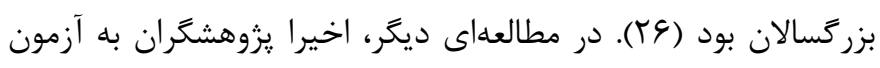

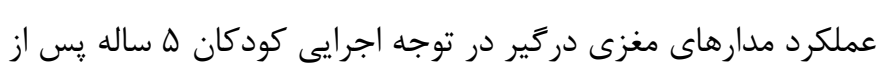

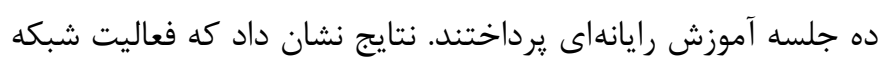

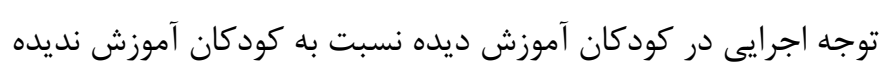

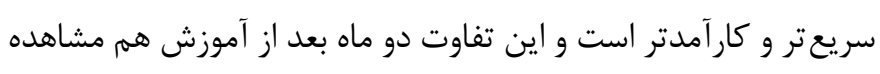

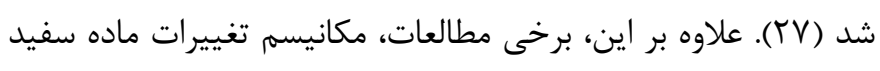

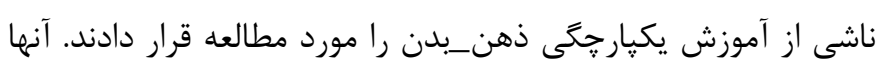

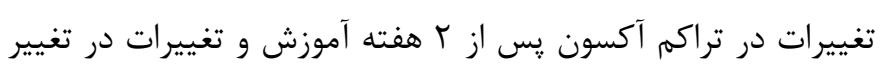

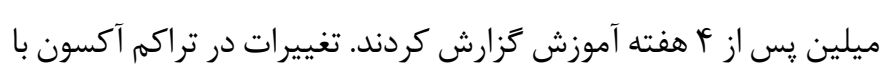

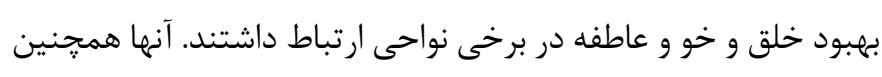

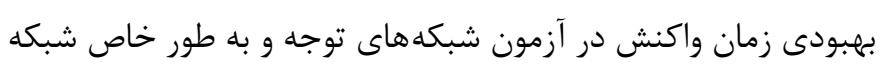

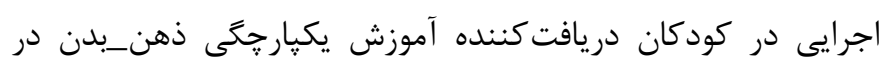

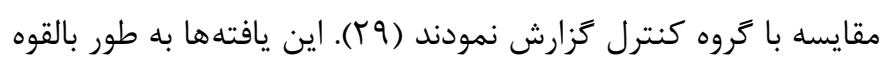

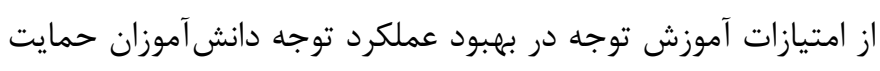

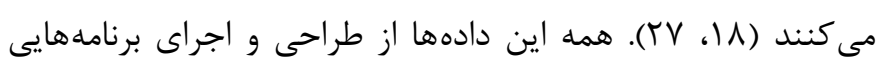

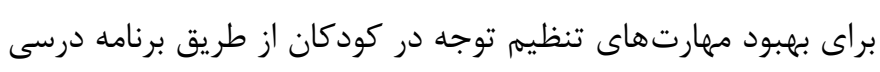
مدرسه حمايت مى كنند (Y)، بV (Y).

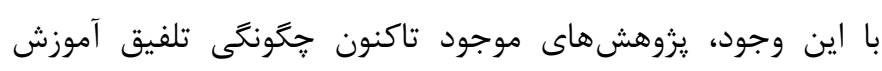

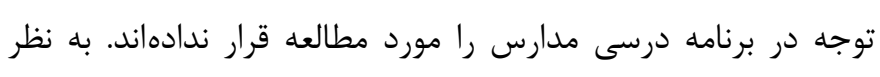

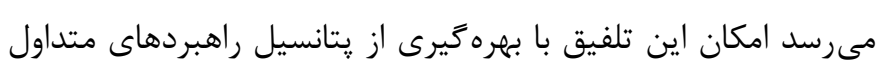

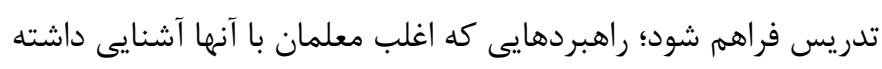

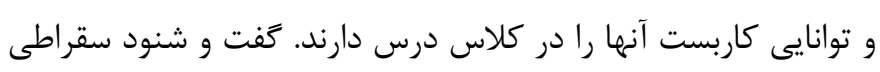

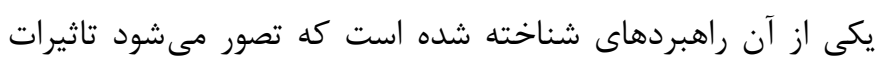

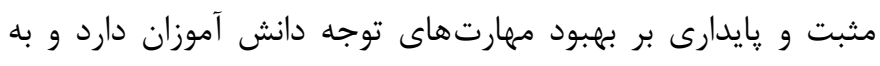

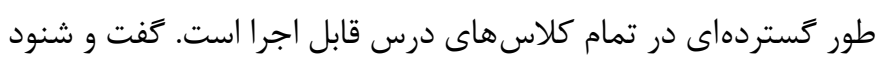

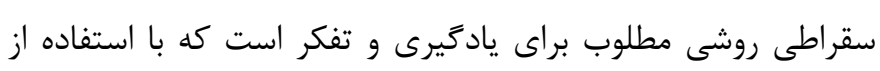

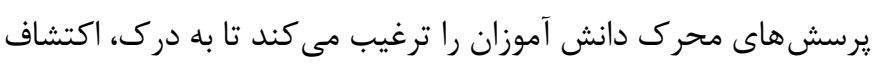

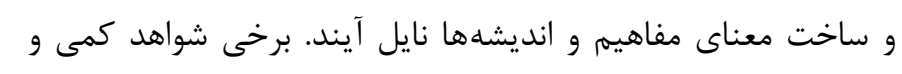

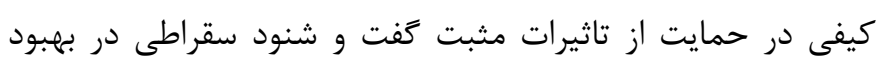

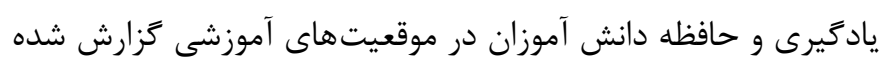

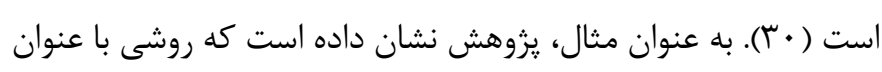
خواندن كفت و شنودى Dialogic reading حتى در سال هاى اوليه

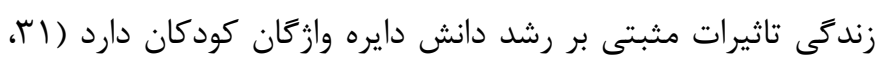

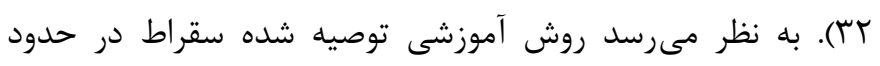


جهت پيكان هدف است. فاصله زمانى از ارايه محرك تا فشار كليد به عنوان زمان واكنش محاسبه مى شود. محركها از يك سطر شامل ينج پِيكان افقى تشكيل شدهاند و تكليف شركت كنند

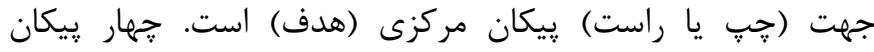

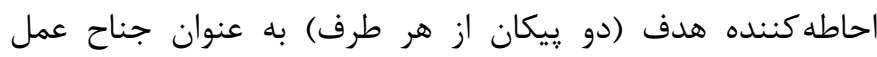

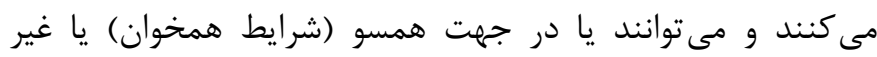

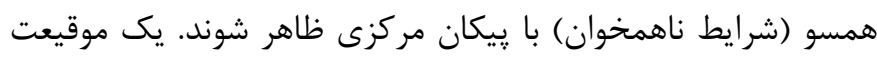
ديخر كه جناح جهار يُيكان بدون جهت هستند، موقعيت خنثى ناميده مىشود. آزمودنى صورت مفروض كنترل كوششمند اجرايى بيشترى بايد داشته باشد تا موقعيت ناهمخوان را به خاطر مداخله جناحها جابجا كند و به تاثير جناح منجر مىشود. اندازهگيرى ميانخين واكنش هر يك از شبكه هاى توجهى از طريق فرمول زير محاسبه شد: 1. شبكه كوش به زنكى = ميانكين زمان واكنش تكاليف بدون نشانهميانكين زمان واكنش تكاليف دو نشانه r. شبكه جهتدهى= ميانگين زمان واكنش تكاليف نشانه مركزىــ ميانكين زمان واكنش تكاليف نشانه فضايى r. شبكه كنترل اجرايى= ميانكين زمان واكنش تكاليف ناهمخوانزمان واكنش تكاليف همخوان ((). همزمان با اجراى آزمون شبكههاى توجه، تغييرات در فعاليت مغزى

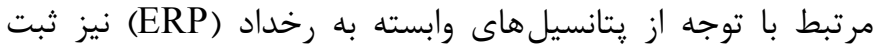

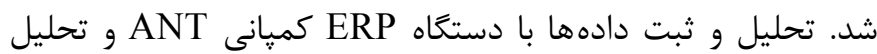
سيخنال ها با نرم افزار MATLAB انجام شد.

\section{Continuous performance آزمون استاندارد توجه پِايدار}

test

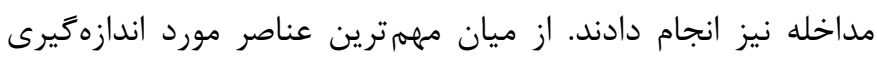

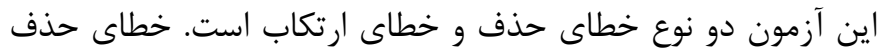
به معناى آن است كه آزمودنى به محرك هدف پاسخ ندهد. در اين شرايط اين جنين تفسير مىشود كه آزمودنى در ادراك محرك و

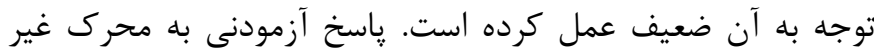

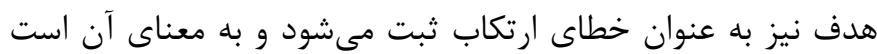

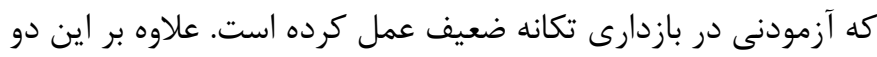

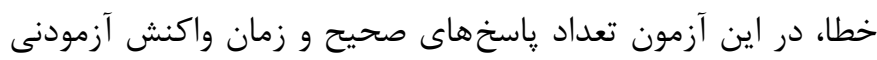

به محرك نيز محاسبه ميشود.

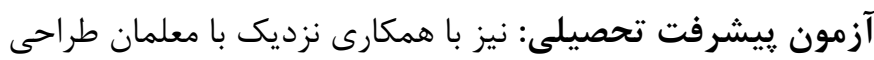

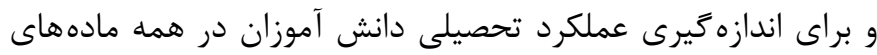

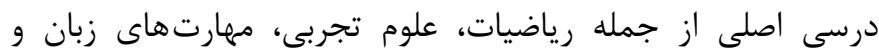
مطالعات اجتماعى اجرا شد.
شركت كنند يايه ششم ابتدايى در يك مدرسه ابتدايى دولتى در شهر تهران بودند. افراد نمونه با توجه به يايه تحصيلى، سن، جنسيت، قوميت، ميزان

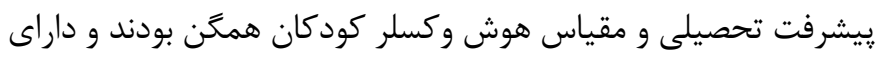

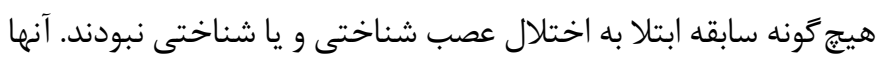

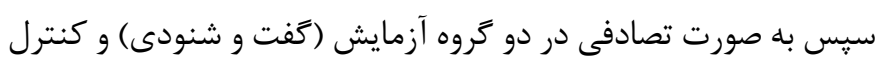

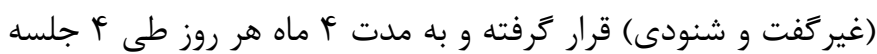
ها دقيقهاى در يزوهش مشاركت داشتند. تعداد ب نفر از ادامه مشاركت در يزوهش انصراف دادند، به طورى كه در يس آزمون تعداد له نفر شركت داشتند. دادههاى بدست آمده از يك دانش آموز تروه آزمايش نيز از فرايند تحليل نهايى به خاطر تكميل نكردن همه اجزاى پيش و

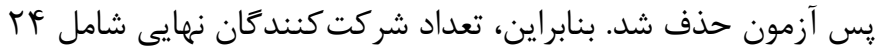

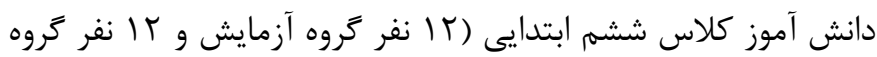

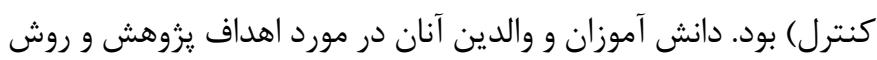

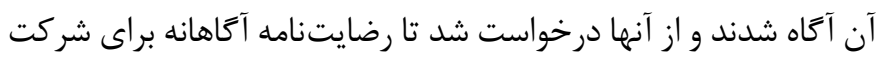

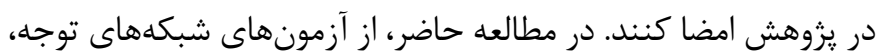
آزمون توجه بايدار، آزمون پيشرفت تحصيلى رياضيات، علوم تجربى، زبان و مطالعات اجتماعى، آزمون هوش و مصاحبه نيمه ساختاريافته

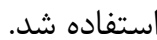

آزمون هاى شبكههاى توجه: از اين آزمون براى كردآروى اطلاعات به

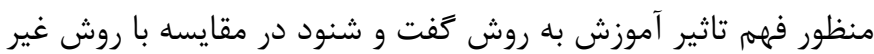
كفت و شنودى بر شبكه هاى عصبى مرتبط با توجه استفاده شد ("ا، 9).

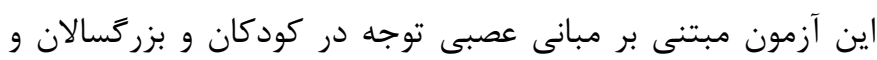

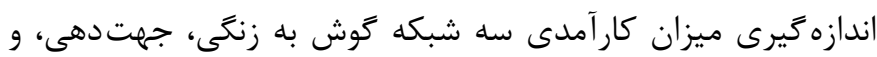
سيستمهاى كنترل اجرايى طراحى شده است (فَ). Fan و همكاران

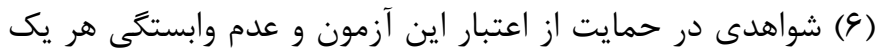

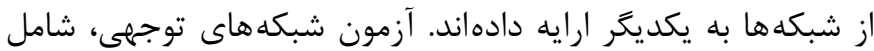
كوششهايى است كه شركت كننده بايد جهت هدف ظاهر شده را در كمترين زمان واكنش به طور صحيح مشخص كند. يك نقطه ثابت مركزى در يك صفحه خالى وجود دارد و هر كوشش با يك نشانه

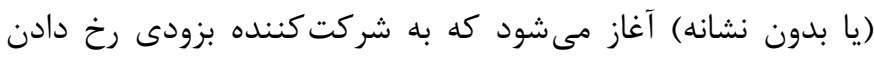

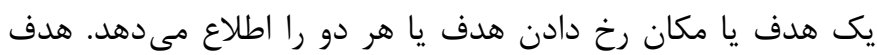
هميشه بالا يا بايين نقطه ثابت مركزى در صفحه نمايان مى شود و از يك پيكان مركزى كه يا به وسيله بِيكان هاى بدون جهت (شرايط

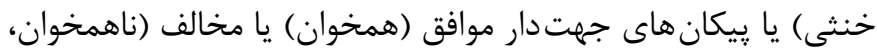
شرايط تعارض ايجاد كننده) احاطه شده تشكيل شده است. ياسخ

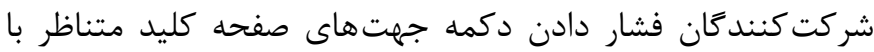




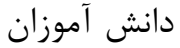

• اختصاص زمان انتظار براى پاسخ دادن و كوش دادن به پِاسخهاى دانش آموزان • هدايت پاسخ هاى دانش آموزان و آغاز درس جديد با يك مجموعه از برسش هاى جديد

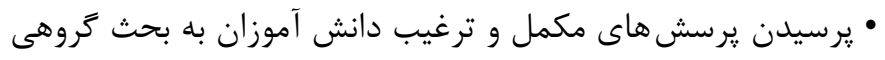

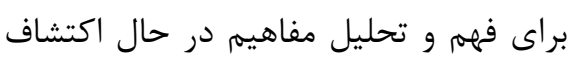

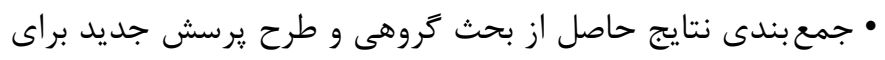

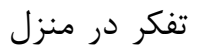
طراحى دروس در روش كفت و شنودى با روش غير كفت و شنودى از اين لحاظ متفاوت بود كه دانش آموزان تحت مداخله روش كفت و

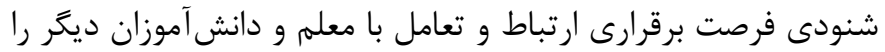
تجربه مى كردند و مطالب درسى با مشاركت فعال همه دانش آموزان

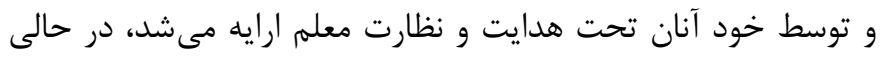

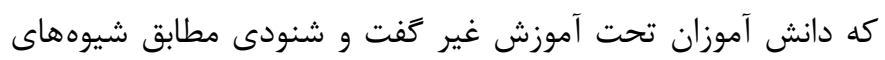

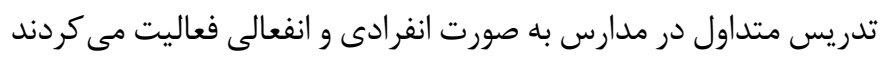

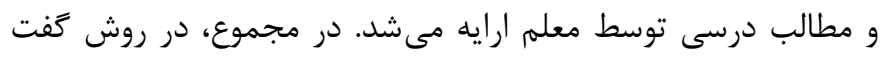

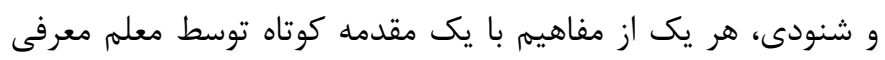

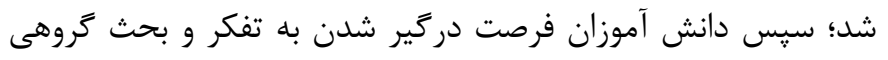

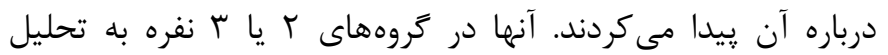

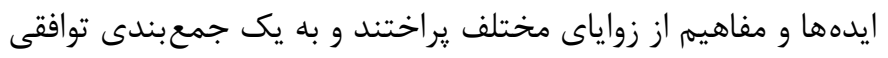

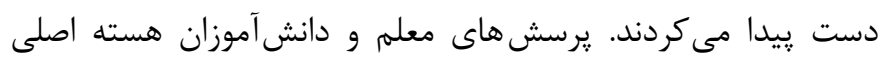

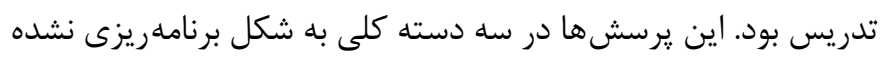

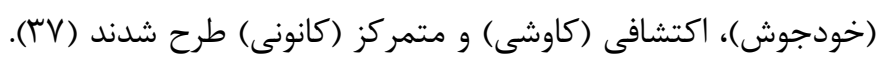

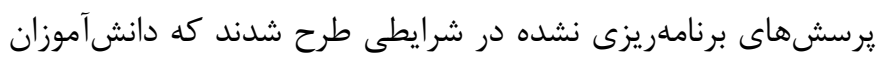

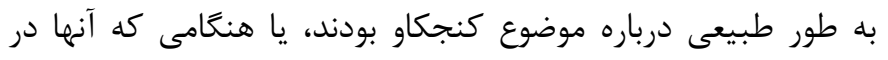

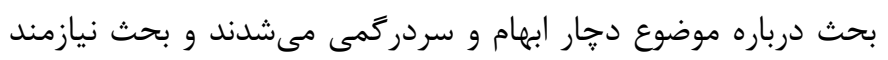

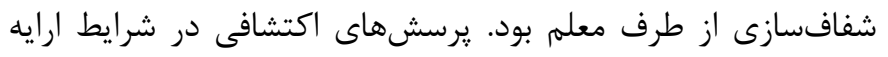

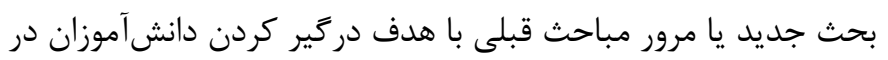

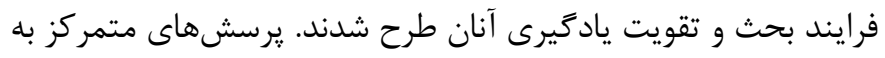

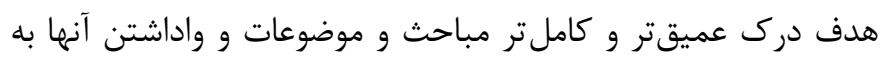

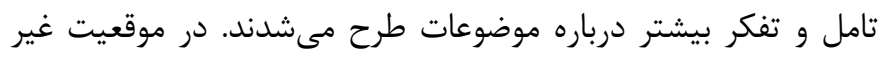

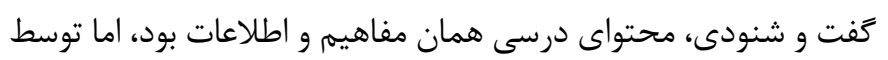

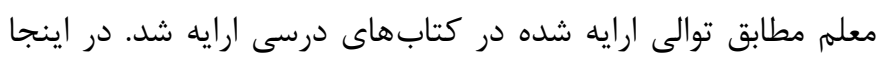

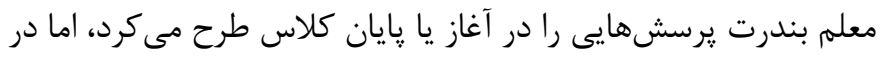

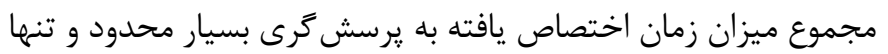

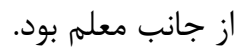

فرم فارسى مقياس هوشى وكسلر براى كودكان Wechsler Intelligence Scale for Children

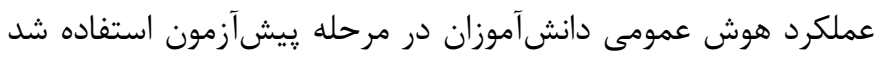

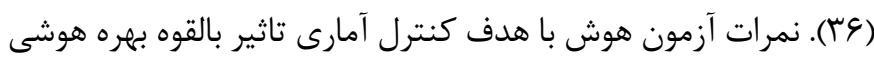

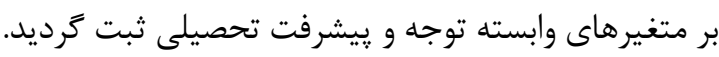

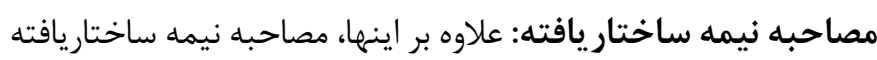

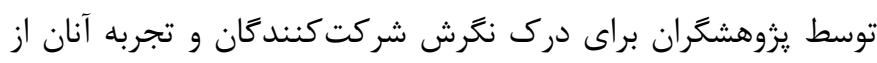

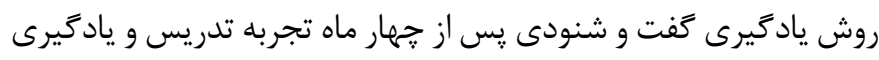

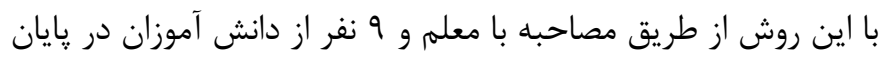
دوره آموزش كفت و شنودى اجرا شد. فرايند اجرا: همه شركت كنند

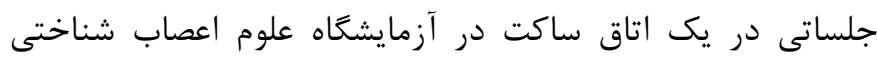

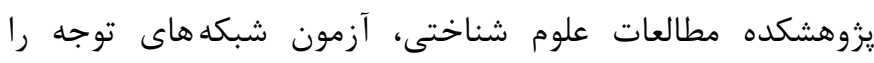

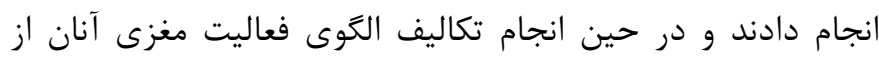

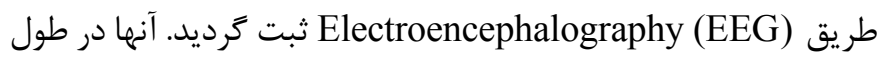
اين جلسات مجموعهاى از تكاليف ديخر مانند آزمون هاى هوش وكسلر،

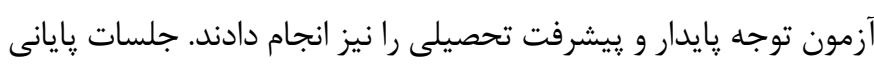

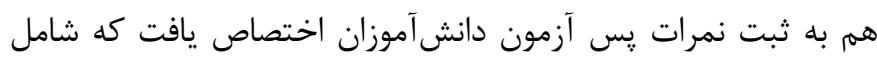

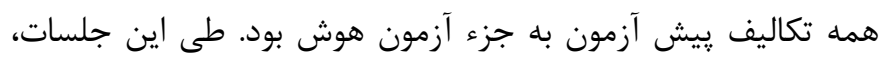

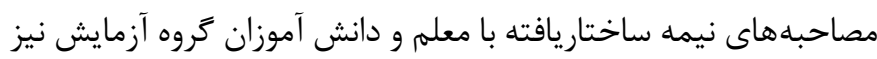

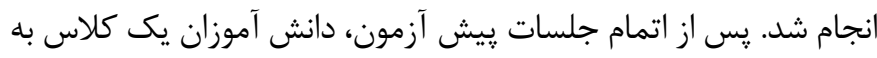

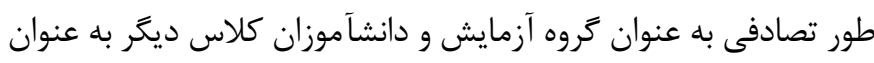

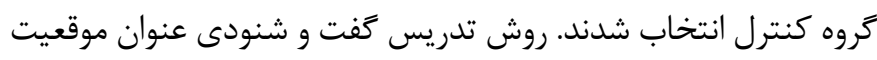

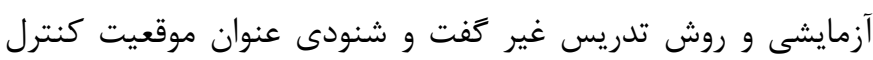
در نظر كرفته شد. شركت كنند

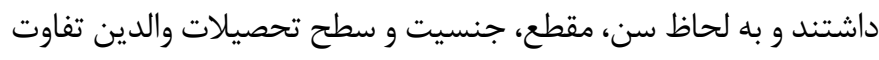

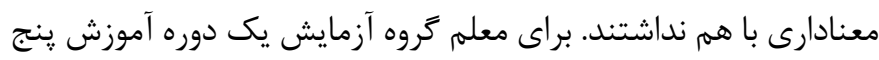

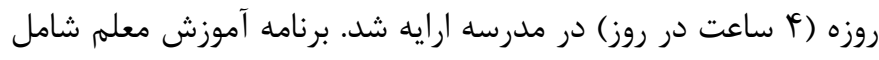

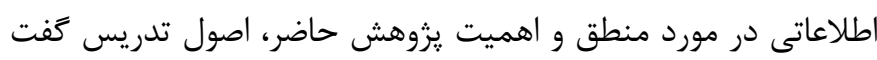

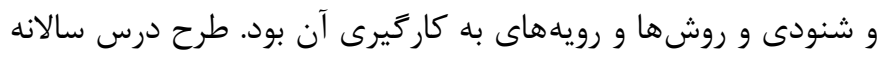

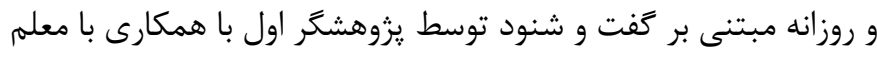
طراحى شد و به طور دقيق توسط ساير همكاران بازنكرى و اصلاح شد.

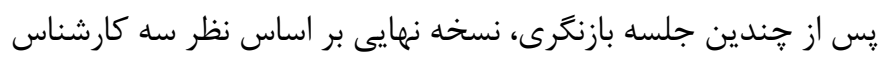

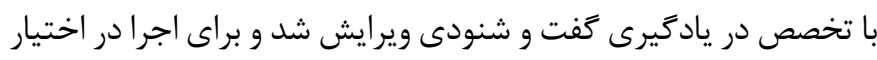

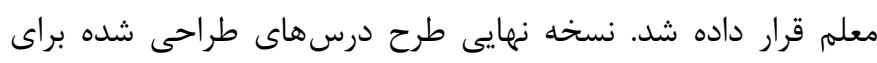
كلاس درس به طور عمومى از فرايند زير تبعيت مى كردند: o يرسيدن يرسشهاى مرتبط براى فعال ساختن دانش پِيشين 
دانشآموزان در آزمونهاى شبكههاى توجه، توجه بِايدار و عملكرد

كافته ها تحصيلى پِ از تعديل تاثير متغيرهاى هميراش هوش و بيش آزمون يافته هاى رفتارى: اين مطالعه با هدف تعيين ميزان اثربخشى روش مورد مقايسه قرار گيرد. نتايج تحليل در جدول ا خلاصه شده است. تدريس كَفت و شنود محور در بهبود عملكرد توجه و عملكرد تحصيلى همانكونه كه در جدول ا مشاهده مىشود، در آزمون شبكه هاى توجه دانش_آموزان קإيه ششم ابتدايى با روش شبه آزمايشى و طرح كروه

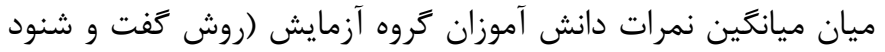

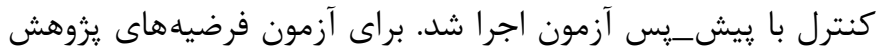
محور) و كروه كنترل (روش غير كَفت و شنودى) در تمامى مولفه هاى اندازه گيرى شده شبكه هاى توجه يعنى گوش به زنكى، جهت

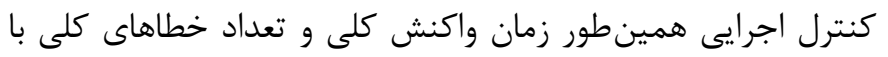
از روش تحليل كوواريانس (ANCOVA) استفاده شد. متغير مستقل در اين يزوهش روش تدريس بود كه به دو شكل كفت و شنودى و غير كفت و شنودى اجرا شد تا تاثيرات هر كدام از اين دو روش بر نمرات

\begin{tabular}{|c|c|c|c|c|c|c|c|c|c|c|c|c|}
\hline \multirow{3}{*}{ اندازه } & \multirow{3}{*}{$\mathbf{P}$} & \multirow{3}{*}{$\mathrm{F}$} & \multirow{3}{*}{ ميانگينور } & \multirow{3}{*}{ دارجادى } & \multicolumn{6}{|c|}{ ميانغَين } & \multirow{3}{*}{ ن } & \multirow{3}{*}{ تكليف } \\
\hline & & & & & \multicolumn{3}{|c|}{ كنترل } & \multicolumn{3}{|c|}{ آزمايش } & & \\
\hline & & & & & ت ت تفاوت & آزمون & آزيش & تفاوت & آزمّن & آيشيش & & \\
\hline .1 .11 & .941 & . ITrA & $\Lambda 91 \cdot \wedge$ & 1.rr & Q/rr & $r r / .9$ & $r r / r q$ & $9 / v 1$ & IV/IF & TEIAD & كوش به زنتىى & \\
\hline$\cdot|Q|$ & 每 & $1 / \cdot v r$ & $|\Delta \wedge \mathrm{V}| \cdot \Delta \Lambda$ & $1, r r$ & $\Delta / \Lambda F$ & $V Q / q T$ & $11 / V V$ & $\mid q / \cdot F$ & $\Lambda \mathrm{V} / \Delta \Lambda$ & $V r / D F$ & جهت دهى & \\
\hline...$r$ & - /Vat & $\cdot / \cdot \vee 1$ & VQ/IT & $1 . r 4$ & $19 / 11$ & $90 / \cdot 1$ & $\wedge F / 19$ & $r F / \Lambda \Lambda$ & $\Delta q / \Delta q$ & $\Lambda F / F V$ & توجه اجرايى & y \\
\hline$\cdot \cdot \cdot r$ & $\cdot|19|$ & $\cdot / \cdot r \mid$ & $r G Y / \cdot V F$ & $1 . r \pi$ & $9 N / \Delta \Lambda$ & $|F| r / \cdot \Lambda$ & $01 \cdot 199$ & $99 / 919$ & FYT/GG & $\Delta / 9 / \Delta \Lambda$ & زمان واكنش كلى & \\
\hline$\cdot / \cdot \Delta \Lambda$ & $\cdot / T V A$ & I/TKT & $\cdot / \ldots$ & 1.rr &.$/ \cdot r \mu$ & 厚 & .1 .49 &.$/ \cdot \uparrow \Lambda$ & .1 .19 & $.1 . f f$ & خطاهاى كل & \\
\hline$\cdot / 11$ &.$/ .49 *$ & $r / f$. & $11 / \wedge 95$ & $1 . r \pi$ & $V / F V$ & $r / \Lambda r$ & $11 / \pi \cdot$ & $91 \cdot 1$ & $\Delta / \cdot \Lambda$ & $11 / 18$ & خطاى حذف & \\
\hline$\cdot 1 \cdot 4$ & . TצG & $\cdot / \Lambda \Delta \Delta$ & $r \varepsilon / T \| 1$ & $1 . r 4$ & $1 / 79$ & $1 \Delta / \Delta$. & $19 / 19$ & $r / \cdot \Lambda$ & $|\Delta / \Delta|$ & $\mid V / 99$ & خطاى ارتكاب & 3 \\
\hline$\cdots / \cdot \varphi$ & $\cdot / q \vee G$ & $\cdot / \Delta T V$ & IFVG/DT. & 1.r & $\mid r / F 9$ & ґর\&/9. & ५१९/.9 & $1 F / \Lambda$ & $r q \Delta / \wedge r$ & 41.194 & زمان واكنش & \\
\hline$\cdot / Q F V$ & . $/ \cdots$ 䄅䄅 & $r F / 19 \varphi$ & $\mid \Lambda k / T q F$ & 1.r & TY/NT & $\Delta T / V T$ & TN/FA & $T V / T$ & $\Delta \mathrm{N} / \cdot 9$ & $r \cdot 119$ & مجموع عملكرد تحصيلى & \\
\hline.$/ \cdot r V$ & rat & . IVAV & $r / \Delta V q$ & 1.r & f/qr & $N / T S$ & T/rr & $\Delta / 9 \Delta$ & $9 / 11$ & $r / \Delta T$ & رياضيات & \\
\hline.$/ 190$ & $\cdot 1 \cdot \uparrow \cdot *$ & $r / \Lambda \Delta$. & $f / r q V$ & 1.r & g/fF & $9 / 99$ & $r / T \Delta$ & $9|\pi|$ & $1 \cdot / V 1$ & $k / f$. & علوم ل & T \\
\hline$\cdot / 1 \Lambda$. & $.1 .49 *$ & F/TVA & G/TRT & 1.r & $9 / \pi 9$ & $1 \cdot 1 \Delta 9$ & $r / T r$ & G/9T & II/AT & $\Delta / r$. & زبان & y \\
\hline$\cdot / r \mid 9$ & $\cdot / . r 9 *$ & $\Delta / \Delta \cdot 9$ & TV/DqV & 1.rr & $9 / \pi 4$ & $r F / l q$ & IV/ar & $N / V I$ & $r g / T r$ & $|V| 99$ & مطالعات اجتماعى & \\
\hline
\end{tabular}


يادگيرى است. بيانات نقل شده زير از معلم به طور صريح ادعاهاى فوق را تاييد مىنمايد: "امن علاقه زيادى به استفاده از تدريس مبتنى بر كَفت و شنود سقراطى

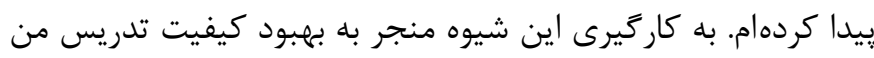

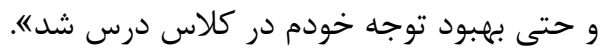

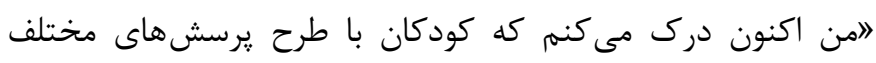

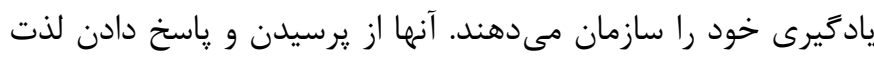
مىبرند و همين باعث مىشود كه كلاس درس به يك محيط يادگيرى فعال و يويا تبديل شود و به باسخهاى همديخر توجه كنند و حتى آنها

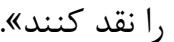
|أكر جه اين نخستين بار بود كه تجربه به كاركيرى اين روش را به صورت منظهم داشته. مديريت كلاس درس در اين روش اكرجه به دليل

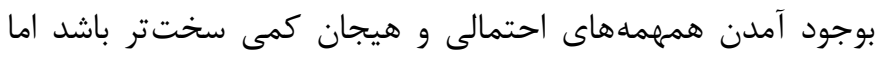

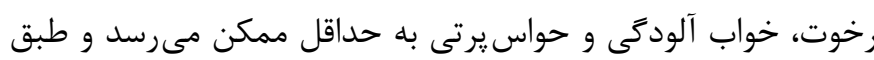
كَفته خود دانش آموزان ديخر منتظر زنق تفريح نيستند و زمان بزودى برى

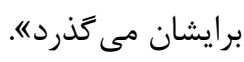

در ياسخ به دشوارىهاى اساسى كاربست تدريس مبتنى بر كفت و شنود سقراطى، معلم شركت كننده در مصاحبه، او نياز بيشتر به زمان و انرزى در استفاده از اين روش اشاره كرد و اظهار داشت: لادر حالى سلى

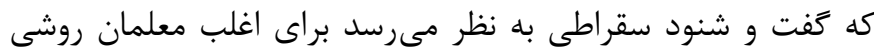
شناخته شده باشد، اما اجراى آن نيازمند زمانى بيشتر از روشهاى نهاى ديخر

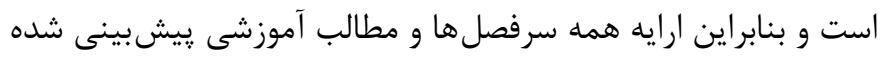

$$
\text { در طول ترم تحصيلى بسيار دشوار مى شوده }
$$

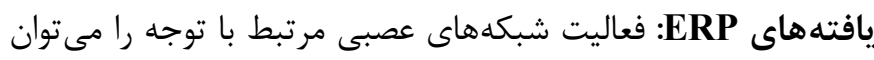

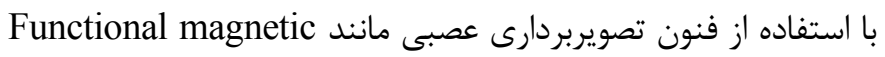

resonance imaging (fMRI)، Diffusion tensor imaging و EEG ترسيم نمود. يزوهشخران با استفاده از fMRI به مطالعه دوره زمانى فعاليت و همبستكى ميان بخشهاى فعال مى يردازند. روش

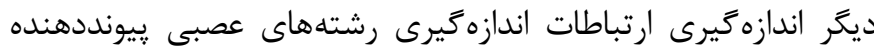

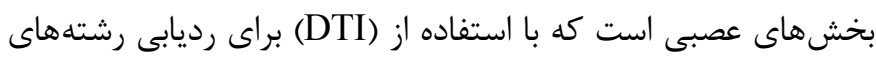

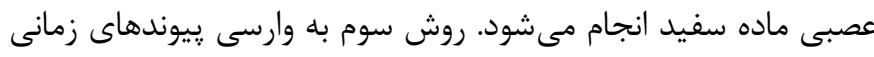

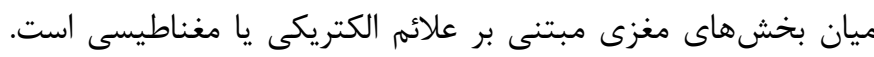

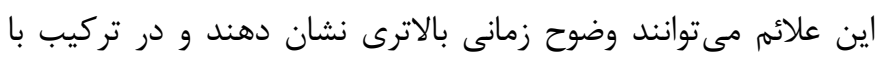

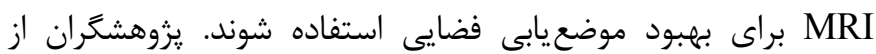

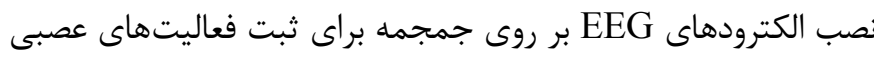
هماهنخ شده در باندهاى فر كانسى مختلف استفاده مى كنند. اين روش مى تواند براى تفكيك رخدادهاى زمانى سريع مانند تفكيك تاثيرات نشانه
وجود عملكرد بهتر گروه آزمايش تفاوتى در سطح معنادار مشاهده نمىشود. همجنين نتايج آنكوا نشان داد كه با وجود بالاتر بودن ميانكَين نمرات كروه آزمايش در هر سه مولفه سنجش شده توجنه يايدار، يعنى خطاى حذف (فشار ندادن كليد در برابر محرك هدف)،

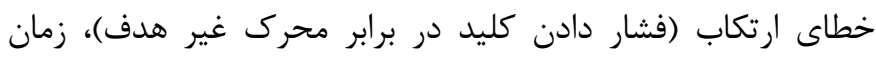

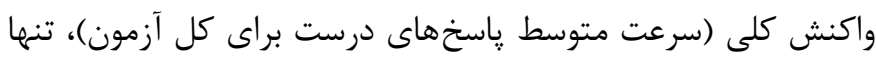

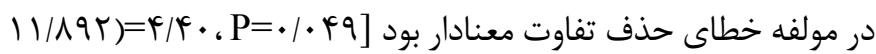
[F(1، آزمون مجموع عملكرد تحصيلى و مواد آن هم نشان داد ميان عملكرد

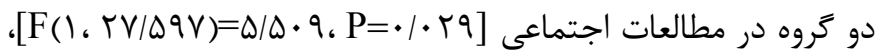

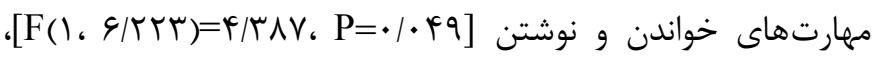

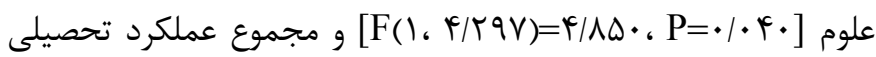

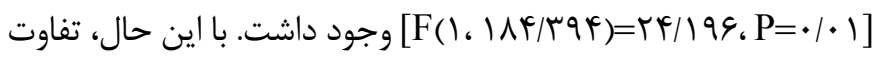

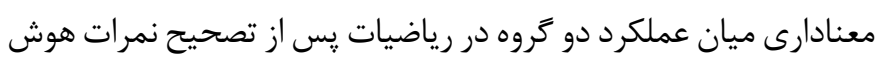

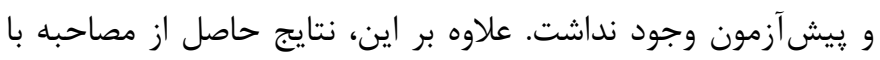

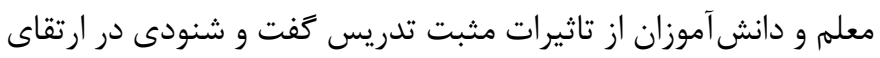
سطح دانش، نكرش و مهارت هاى آنان يشتيبانى مى كند. دانش آموزان از تاثيرات مثبت تدريس كفت و شنودى بر يادكيرى خود رضايت داشتند.

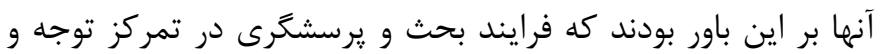

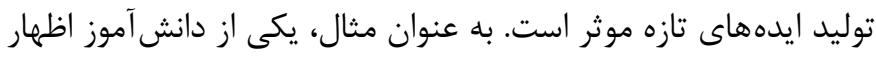

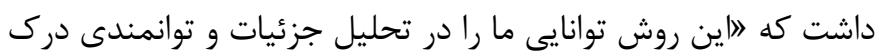

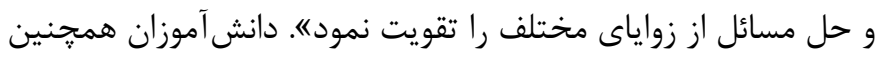

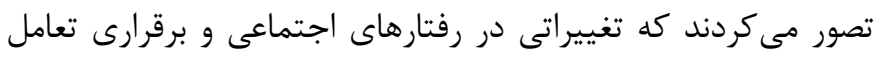

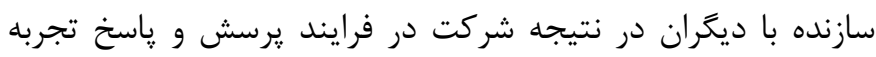

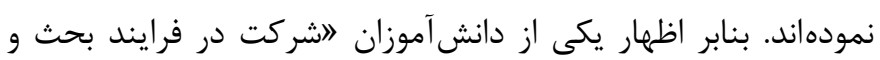

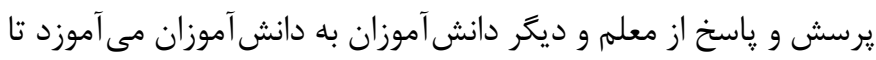
به نظرات مختلف توجه كنند و انتقادات را بيذيرنده. به اعتقاد معلم، استفاده از تدريس كَفت و شنودى تدريس او او را كار آمدتر ساخته است. او روش تدريس مبتنى بر كَت و شنود سقراطى را به

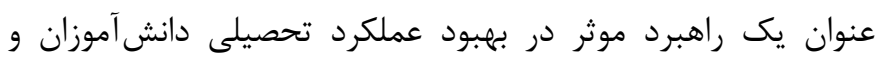

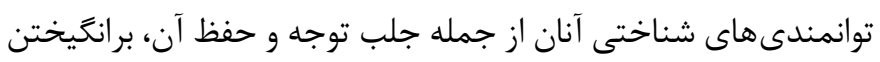
توان تخيل و خلاقيت و ارتقاى مهارتهاى تنظيم هيجان و تعامل

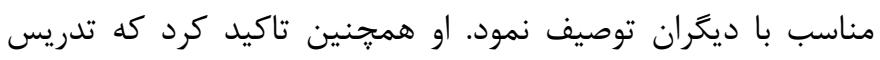

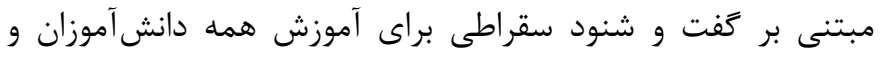
براى تدريس همه موضوعات درسى سودمند است. به اعتقاد معلم، روش كفت و شنود سقراطى روشى موثر براى تقويت توانمندى توجه

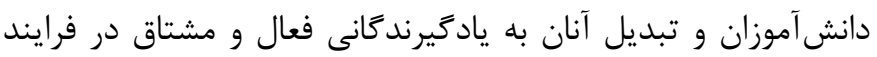


دست آمده در جدول (Y) خلاصه شده است: نتايج ERP خلاصه شده در جدول r نشان مى دهد كه ميان دو كروه

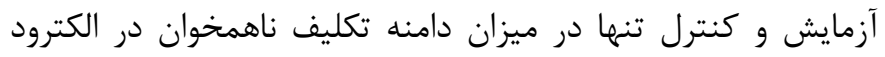

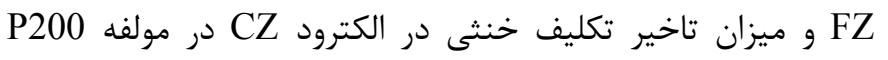

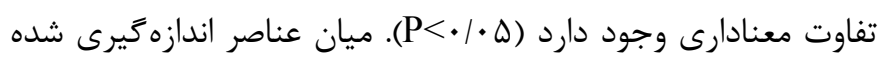

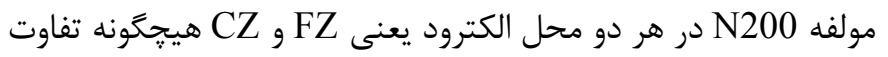

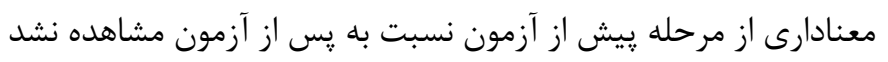

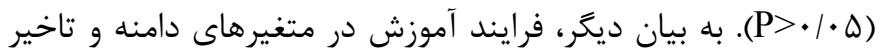
مولفه N2 در هيج يك از تكاليف آزمون تاثير قابل توجهى نداشته است. اين فرايند تغييرات در شكل (1) قابل مشاهده است.

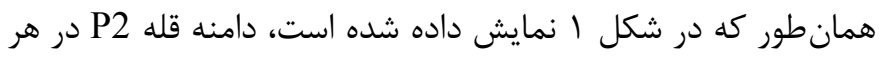

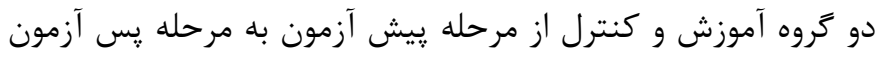

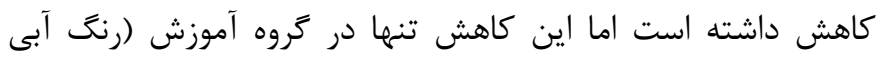

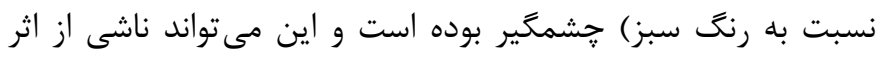

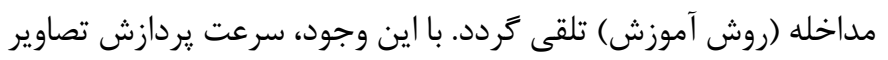

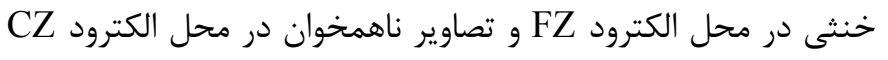
نيز در مرز معنادارى قرار دارند (مقادير معنادارى براى آنها به ترتيب

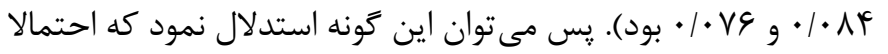
آموزش كفت و شنود سقراطى بر سرعت يردازش تصاوير ناهمخوان و خنثى (فارق از محل جايخيرى الكترودها) تاثير مثبت دارد.

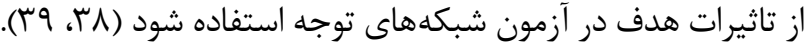

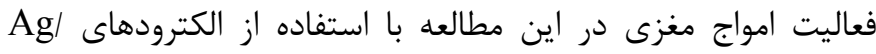
AgCl

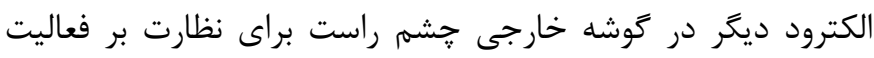

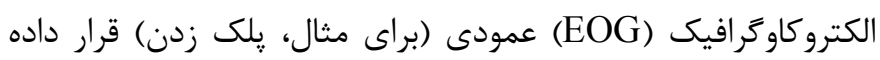

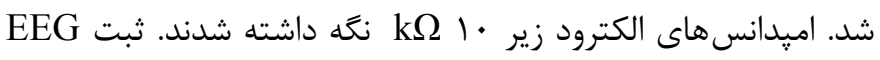

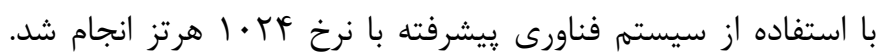
دادهها مجددا به مرجع متوسط تبديل شدند و از يك فيلتر ميان كذر

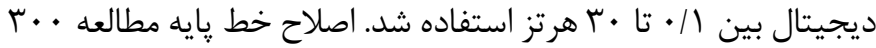
ميلىثانيه قبل از شروع از محرك هدف انجام شد. دادههاى به دست آمده در حالت آفلاين وارد نرمافزار با קاسخهاى نادرست يا خارج از محدوده زمان واكنش قابل يذيرش

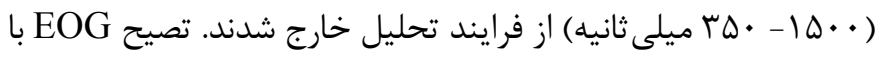

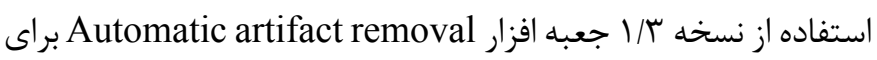
MATLAB انجام شد و به كل Y ثانيه از هر كوشش بكار ترفته شد.

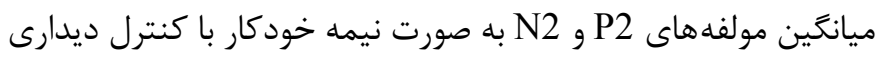
تعيين شد. اين مولفهها در FZ , CZ به عنوان انحراف مثبت (منفى)

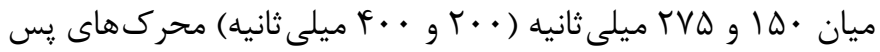
از هدف تحليل شدند. زمان نهفتگى و دامنه مولفههاى P2 و N2 اين ينجرههاى زمانى بر اساس قواعد معرفى شده اندازهيرى شد. نتايج به
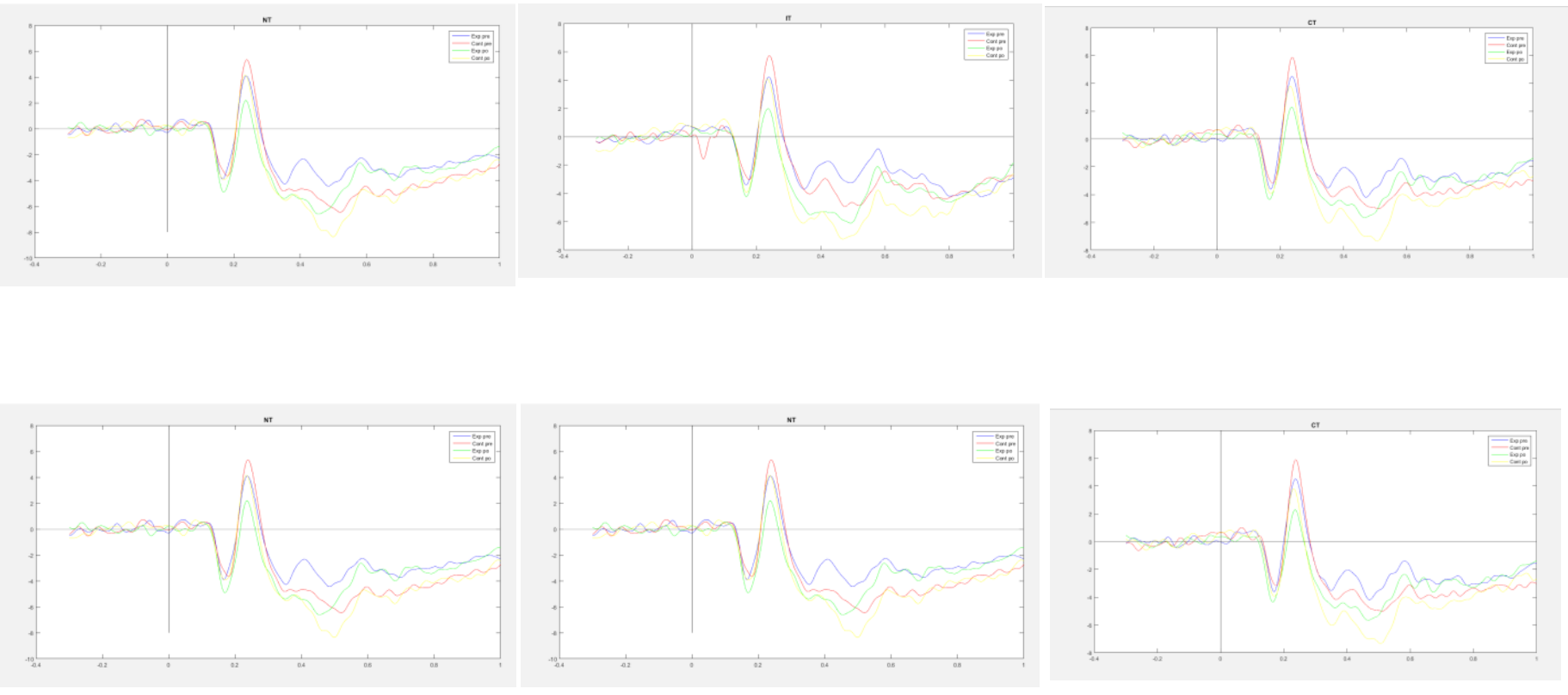

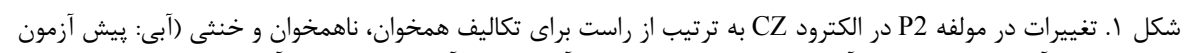

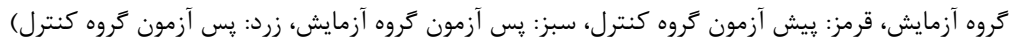


جدول r. نتايج آزمون كروههاى مستقل براى مولفهاى P200 و N200

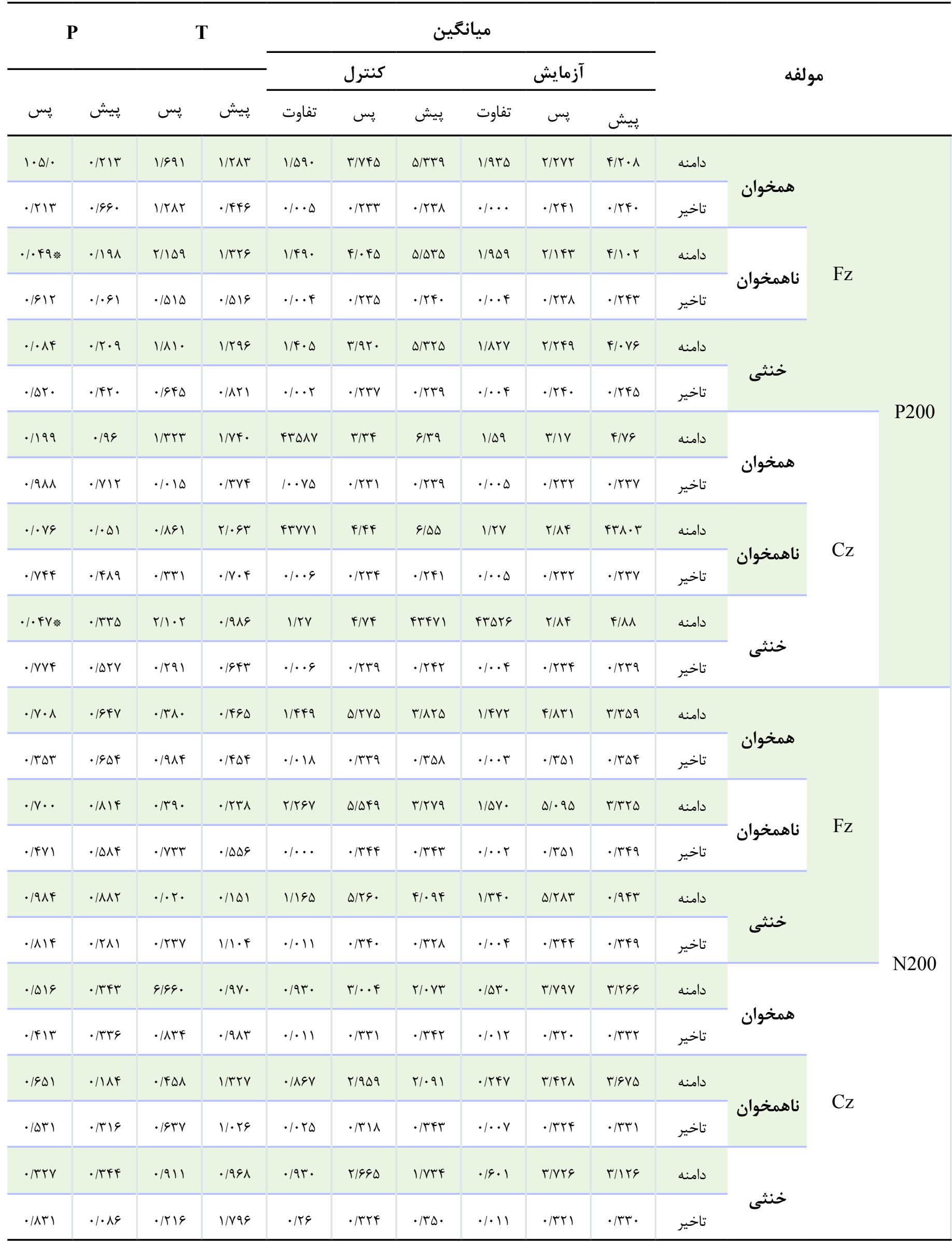


كَفت و شنودى در بهبود توجه و همين طور عملكرد تحصيلى است. تفاوت

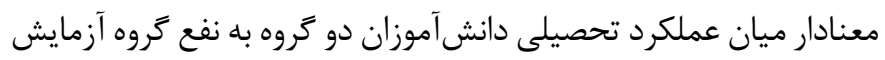

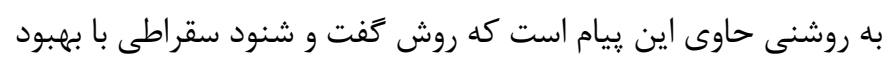

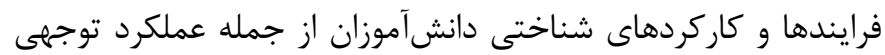
آنان منجر به بهبود عملكرد تحصيلى آنان مىشود. عملكرد شناختى و به اله تبع آن عملكرد تحصيلى بهتر دانش آموزان آموزش ديده با روش كَفت و شنود سقراطى نسبت به روش غير كفت و شنودى به احتمال زياد ناشى از جنبه يرسش گرانه كَفت و شنود است كه بِيوسته توجه دانشآموزان

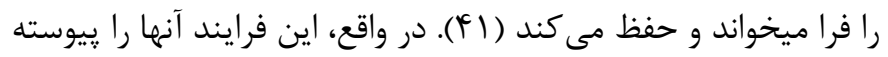

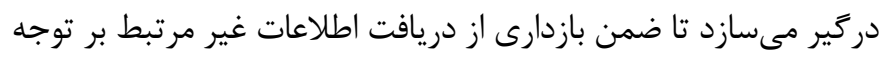

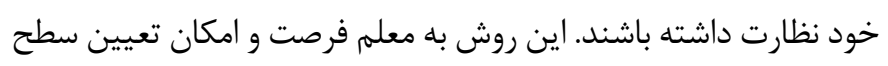

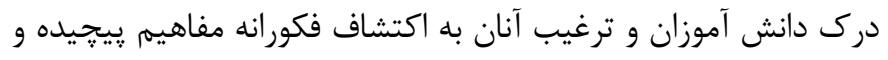
ساخت دانش معنادار را مى دهد. همجنين ممكن است ناشى از تاثير يرسشكرى در تغيير توجه دانش آموزان به تمركز بر موقعيت يادكيرى و در نتيجه تسهيل يادكيرى و يادآورى آنها باشد. همانكونه Posner

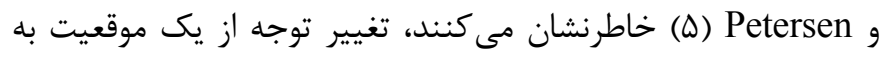
موقعيت ديخر كار سادهاى نيست، بلكه نيازمند سه فعاليت اساسى:

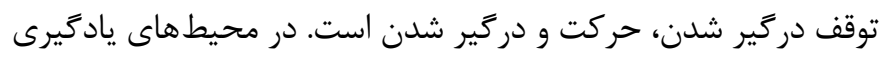

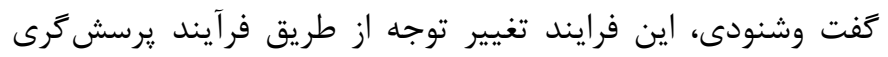

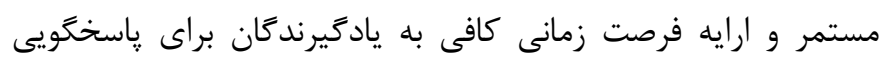

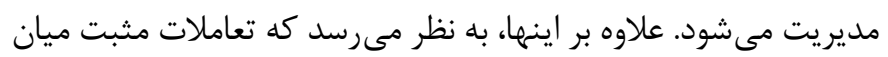

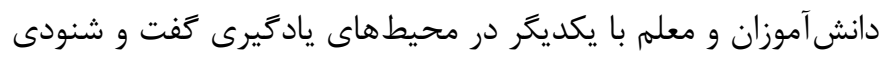
احساس شايستىى و انگَيزه درونى دانش آموزان به يادَيرى را تحريك و بهبود مى بخشد. اين بدان معناست كه تدريس كفت و شنود محور منجر به بهبود توانايى كنترل كوششمند مىشود. كنترل كوششمند يكى

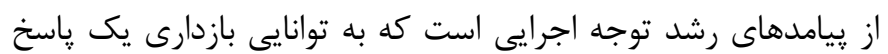

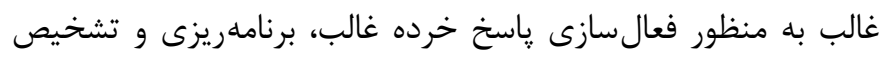

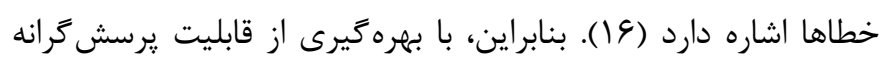

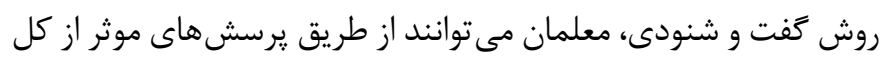

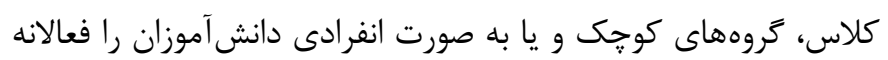

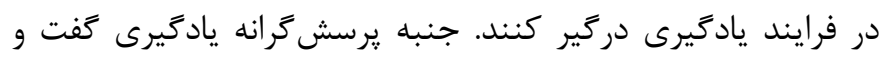
شنودى آن را به يكى از برجستهترين جلوههاى جهان شمول مبدل ديرل

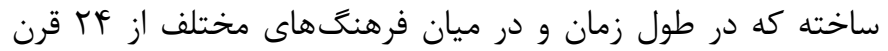
ييش تاكنون به عنوان روشى موثر و سودمند براى ياديرى و تفكر بكار

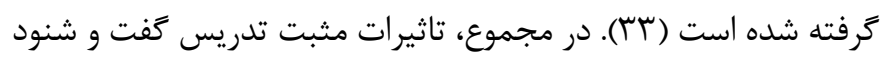

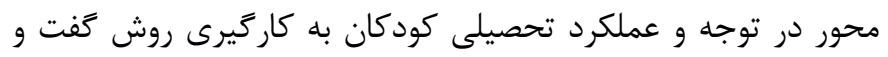

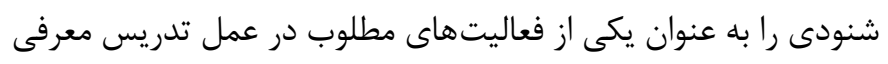

يكى از نكرانىهاى جدى معلمان امروزى دستيابى به راههايى براى

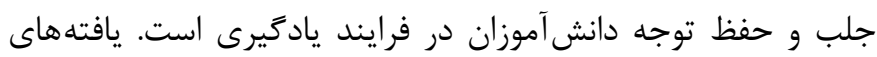
ارائه شده در يزوهش حاضر به روشنى نقش مههم يادگيرى كفت و شنودى در كاهش קنين نغرانى هايى را مستند مى سازد. نتايج حاصل

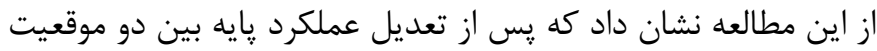
كفت و شنودى و غير كفت و شنودى در ميانكين نمرات شبكههاى كنترل اجرايى توجه، كوش به زنتى، جهتدهى، مجموع زمان واكنش

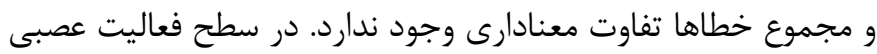

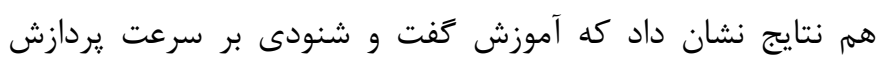

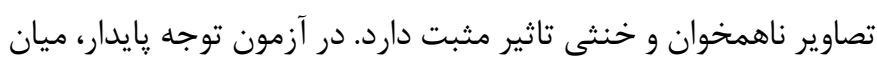

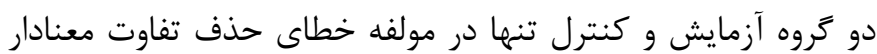
مشاهده شد. همجنين نتايج نشان داد كه ميان ميانخين نمرات بيشرفت تحصيلى دانش آموزان كروه آزمايش و گروه كنترل در همه مواد آزمون شده (غير از رياضى) تفاوت معنادار وجود دارد. علاوه بر اين، دادههاى كيفى حاصل از مصاحبه نيز از برترى روش كفت و شنودى بر روش

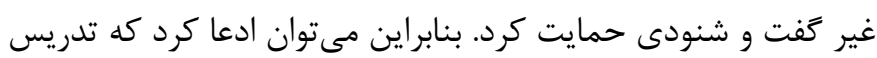

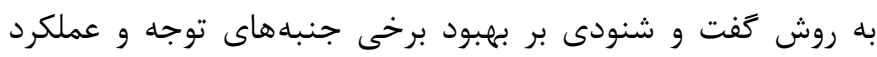
تحصيلى دانش آموزان تاثير دارد.

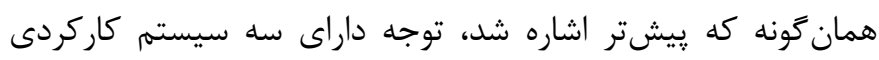

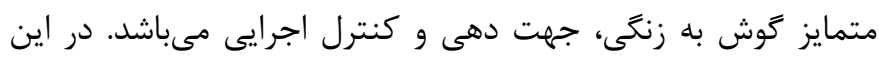

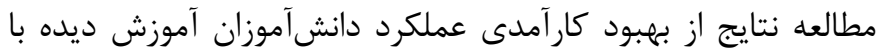
روش كفت و شنودى در شبكه كنترل اجرايى حمايت كرد. توجه به طور كلى به عنوان فرايند شناختى انتخاب اطلاعات مرتبط از محيط و بازدارى از دريافت اطلاعات غير مرتبط تعريف شده است. كنترل اجرايى به عنوان توانمندى كنترل رفتارى براى دستيابى به اهداف قصد شده داريط

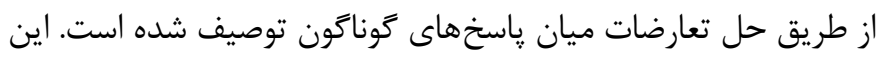

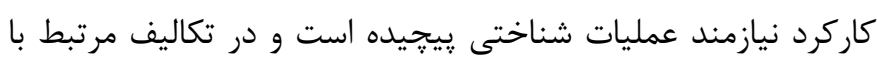

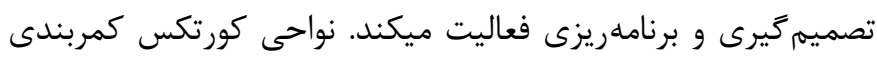
زيرين و ويش بيشانى جانبى با اين كاركرد مرتبط هستند (1) (1). نتايج

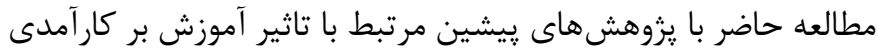

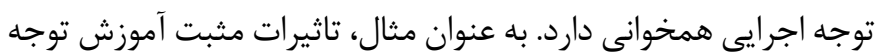
بر شبكه توجه اجرايى (YY)؛ تاثيرات مثبت تمرينات مراقبه كوتاه مدت

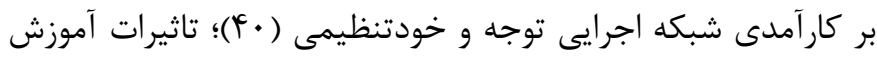

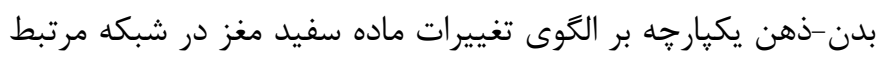

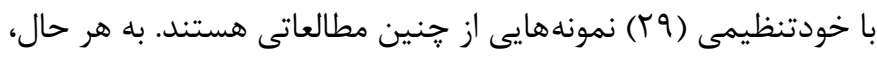

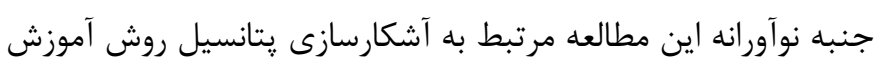




\section{نتيجه كيرى}

نتايج اين يزوهش از تاثيرات مثبت تدريس با روش كفت و شنود سقراطى در بهبود برخى جنبههاى توجه و عملكرد تحصيلى حمايت مى كند. اين تاثيرات به احتمال زياد ناشى از ماهيت يرسش فضاى يادگيرى كفت و شنود است كه دانشآموزان را ترغيب مى كند تا ييوسته فرايندهاى توجه خود را مديريت و نظارت نمايند.

\section{تشكر و قنرواذى}

اين مقاله برگرفته از طرح يزوهشى تحت حمايت ستاد توسعه علوم و

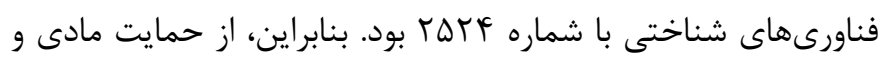
معنوى آن مركز براى انجام اين يزوهش تقدير و تشكر مى

\section{References}

1.Wang YF, Cui Q, Liu F, Huo YJ, Lu FM, Chen H, et al. A new method for computing attention network scores and relationships between attention networks. PloS One. 2014;9(3):e89733. 2. Fan J, Byrne J, Worden MS, Guise KG, McCandliss BD, Fossella $\mathrm{J}$, et al. The relation of brain oscillations to attentional networks. Journal of Neuroscience. 2007;27(23):6197-6206.

3. Posner MI, Rothbart MK. Influencing brain networks: implications for education. Trends in Cognitive Sciences. 2005;9(3):99-103.

4. Posner MI, Rothbart MK, Rueda MR. Brain mechanisms and learning of high level skills. In: Battro AM, Fischer KW, Lena PJ, editors. The educated brain: Essays in neuroeducation. Cambridge:Cambridge University Press;2008. pp. 151-165.

5. Posner MI, Petersen SE. The attention system of the human brain. Annual Review of Neuroscience. 1990;13(1):25-42.

6. Fan J, McCandliss BD, Sommer T, Raz A, Posner MI. Testing the efficiency and independence of attentional networks. Journal of Cognitive Neuroscience. 2002;14(3):340-347.

7. Posner MI, Rothbart MK. Educating the human brain. Washington:American Psychological Association;2006.

8. Fan J, Gu X, Guise KG, Liu X, Fossella J, Wang H, et al.

Testing the behavioral interaction and integration of attentional
مى كند كه كارآمدى آن مبتنى بر شواهد يثرهشى تاييد شده است. اين مطالعه داراى محدويتهايى بود. اين مطالعه، در طول يك دوره نسبتا كوتاه زمانى (جهار ماهه) و تنها در يك گايه تحصيلى (يايه ششم) اجرا شد. اجراى آن با يك مطالعه همخَروهى با مقايسه روش هاى مختلف

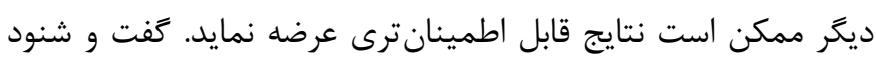
سقراطى اجرا شده در اين مطالعه تنها يكى از راهبردهاى معروف از ميان راهبردهاى مختلف كفت و شنودى است. مطالعات آينده لازم است به مقايسه تاثيرات انواع مختلف راهبردهاى مختلف كفت و شنودى بر عملكرد تحصيلى دانش آموزان بِردازند. همجنين لازم است كه فعاليت مغزى ميان دانش آموزان و معلم در حين كفت و شنود نيز مورد بررسى قرار گيرد.

networks. Brain and Cognition. 2009;70(2):209-220.

9. Fan J, McCandliss BD, Fossella J, Flombaum JI, Posner MI. The activation of attentional networks. Neuroimage. 2005;26(2):471-479.

10. Fan J, Wu Y, Fossella JA, Posner MI. Assessing the heritability of attentional networks. BMC Neuroscience. 2001;2(1):14.

11. Posner MI, Sheese BE, Odludaş Y, Tang Y. Analyzing and shaping human attentional networks. Neural networks. 2006;19(9):1422-1429.

12. Rueda MR, Fan J, McCandliss BD, Halparin JD, Gruber DB, Lercari LP, et al. Development of attentional networks in childhood. Neuropsychologia. 2004;42(8):1029-1040.

13. Petersen SE, Posner MI. The attention system of the human brain: 20 years after. Annual review of Neuroscience. 2012;35:73-89.

14. Konrad K, Neufang S, Thiel CM, Specht K, Hanisch C, Fan J, et al. Development of attentional networks: An fMRI study with children and adults. Neuroimage. 2005;28(2):429-439.

15. Posner MI, Rothbart MK. Attention to learning of school subjects. Trends in Neuroscience and Education. 2014;3(1):14-17.

16. Rothbart MK, Ellis LK, Rosario Rueda M, Posner MI. Developing mechanisms of temperamental effortful control. Jour- 
nal of Personality. 2003;71(6):1113-1144.

17. Simonds J, Kieras JE, Rueda MR, Rothbart MK. Effortful control, executive attention, and emotional regulation in 7-10-year-old children. Cognitive Development. 2007;22(4):474-488.

18. Raz A, Buhle J. Typologies of attentional networks. Nature Reviews Neuroscience. 2006;7(5):367-379.

19. Rueda MR, Posner MI, Rothbart MK. The development of executive attention: Contributions to the emergence of self-regulation. Developmental Neuropsychology. 2005;28(2):573-594.

20. Posner MI, Rothbart MK, Sheese BE, Voelker P. Developing attention: Behavioral and brain mechanisms. Advances in Neuroscience. 2014;2014:405094.

21. Racer KH, Gilbert TT, Luu P, Felver-Gant J, Abdullaev Y, Dishion TJ. Attention network performance and psychopathic symptoms in early adolescence: An ERP study. Journal of Abnormal child Psychology. 2011;39(7):1001.

22. Kerns KA, Eso K, and Thomson J. Investigation of a direct intervention for improving attention in young children with ADHD. Developmental Neuropsychology. 1999;16(2):273-295.

23. Cortese S, Ferrin M, Brandeis D, Buitelaar J, Daley D, Dittmann RW, et al. Cognitive training for attention-deficit/ hyperactivity disorder: Meta-analysis of clinical and neuropsychological outcomes from randomized controlled trials. Journal of the American Academy of Child \& Adolescent Psychiatry. 2015;54(3):164-174.

24. Tucha O, Tucha L, Kaumann G, König S, Lange KM, Stasik $\mathrm{D}$, et al. Training of attention functions in children with attention deficit hyperactivity disorder. ADHD Attention Deficit and Hyperactivity Disorders. 2011;3(3):271-283.

25. Esmaeeli F, Nouri A, and Moradi A. The impact of computerized attention oriented games on attention networks and temperament of students with attention deficit/hyperactivity disorder. Journal of Exceptional Children. 2016;16(1):5-19. (Persian) 26. Rueda MR, Rothbart MK, McCandliss BD, Saccomanno L, Posner MI. Training, maturation, and genetic influences on the development of executive attention. Proceedings of the na- tional Academy of Sciences of the United States of America. 2005;102(41):14931-14936.

27. Rueda MR, Checa P, Cómbita LM. Enhanced efficiency of the executive attention network after training in preschool children: immediate changes and effects after two months. Developmental cognitive Neuroscience. 2012;2:S192-204.

28. Tang YY, Posner MI. Attention training and attention state training. Trends in Cognitive sciences. 2009;13(5):222-227.

29. Tang YY, Lu Q, Fan M, Yang Y, and Posner MI. Mechanisms of white matter changes induced by meditation. Proceedings of the National Academy of Sciences. 2012;109(26):10570-10574. 30. Pihlgren AS. Socrates in the classroom: Rationales and effects of philosophizing with children. [PhD Dissertation]. Stockholm:Stockholm University;2008.

31. Chow BW, McBride-Chang C, Cheung H, Chow CS. Dialogic reading and morphology training in Chinese children: Effects on language and literacy. Developmental Psychology. 2008;44(1):233-244.

32. Fung PC, Chow BW, McBride-Chang C. The impact of a dialogic reading program on deaf and hard-of-hearing kindergarten and early primary school-aged students in Hong Kong. Journal of Deaf Studies and Deaf Education. 2005;10(1):82-95. 33. Goldin AP, Pezzatti L, Battro AM, Sigman M. From ancient Greece to modern education: Universality and lack of generalization of the Socratic dialogue. Mind, Brain, and Education. 2011;5(4):180-185.

34. Battro AM. The Teaching brain. Mind, Brain, and Education. 2010;4(1):28-33.

35. Fan J, Posner M. Human attentional networks. Psychiatrische Praxis. 2004;31(S2):210-214.

36. Karami A. Wechsler intelligence scale for children (IV): Implementing and grading guide / David Wechsler. Tehran:Ravansanji publications;2007. (In Persian)

37. Paul R, Elder L. Critical thinking: The art of Socratic questioning, part III. Journal of Developmental Education. 2008;31(3):34- 45.

38. Purves D, Cabeza R, Huettel SA, LaBar KS, Platt ML, 
Woldorff MG, et al. Cognitive Neuroscience. Sunderland:Sinauer Associates, Inc;2008.

39. Desimone R, Duncan J. Neural mechanisms of selective visual attention. Annual Review of Neuroscience. 1995;18(1):193-222.

40. Tang YY, Ma Y, Wang J, Fan Y, Feng S, Lu Q, et al. Short- term meditation training improves attention and self-regulation. Proceedings of the National Academy of Sciences. 2007;104(43):17152-17156.

41. Halpain DR, Glover JA, Harvey AL. Differential effects of higher and lower order questions: Attention hypotheses. Journal of Educational Psychology. 1985;77(6):703-715. 